Arab Journal of Sciences

and Research Publishing

Volume (7), Issue (4): 30 Dec 2021

P: 1 - 21
AJSRP

ISSN: 2518- 5780
المجلة العربية للعلوم

ونشـر الأبحـاث

المجلد (7)، العدد (4): 30 ديسمبر 2021 م

ص: 1 - 11

\title{
The use of modern television technology and its impact on increasing viewing of news programs on Jordanian television from the perspective of employees and technicians working in the news programs
}

\author{
Malik Rehab Al- Azza \\ Jordan Television \\ Ezzat Moh'd Hijab \\ Middle East University || Jordan
}

\begin{abstract}
The study aimed to uncover the level of use of modern television technologies and their impact on increasing the watching of news programs on Jordanian television. The study used a descriptive and analytical approach, and the data were collected through developing a scale for the use of modern television technologies for news programs. The sample of the study consisted of (110) workers and technicians in news programs on Jordanian television, chosen by the available deliberate sample method.

The results of the study showed that the use of modern television technologies increases the degree of television viewing, especially watching news programs. The study also showed that Jordanian television still uses old television technologies.

The study recommended the necessity of transforming Jordanian television into the HD broadcasting technology system instead of the SD system and working on training employees on modern television technologies (infographic, graphics, audio effects, and visual effects).
\end{abstract}

Keywords: modern television technologies, news programs, Jordanian television.

$$
\begin{aligned}
& \text { استخدام التقنيات التلفزيونية الحديثة وأثرها في زيادة متابعة مشـاهدة البرامج } \\
& \text { الإخبارية في التلفزيون الأردني من وجهة نظر العاملين والفنيين العاملين في البرامج } \\
& \text { الإخبارية } \\
& \text { مالك رحاب العزة } \\
& \text { التلفزيون الأردني } \\
& \text { عزت محمد حجاب } \\
& \text { جامعة الشرق الأوسط || الأردن }
\end{aligned}
$$

المستخلص: هدفت هذه الدراسة إلى الكشف عن مستوى استخدام التقنيات التلفزيونية الحديثة وأثرها على زيادة متابعة مشاهدة

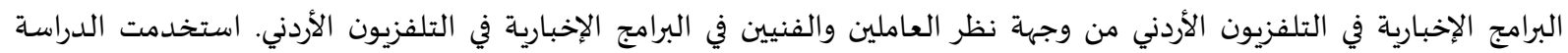
المنهج الوصفي التحليلي، وتم جمع البيانات من خلال تطوير مقياس لاستخدام التقنيات التلفزيونية الحديثة للبرامج الإخبارية، وتم

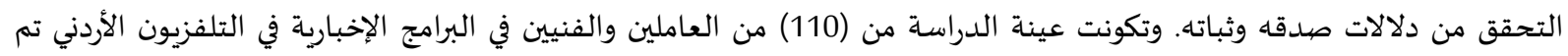
اختيارهم بطريقة العينة العمدية القصدية. 


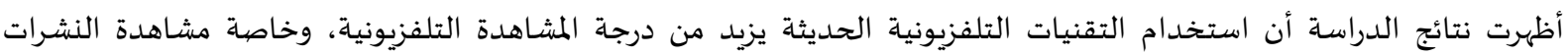

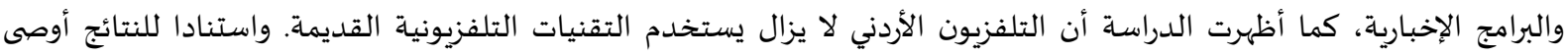

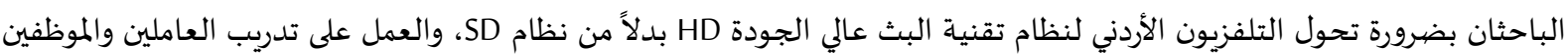

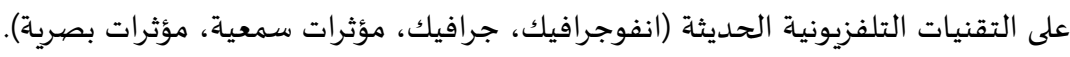
الكلمات المفتاحية: التقنيات التلفزيونية الحديثة، البرامج والنشرات الإخبارية، التلفزيون الأردني.

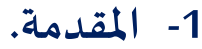

في ظل التغيرات السريعة والحديثة في مجال الإعلام، نجد أن الإعلام التلفزيوني يسعى إلى التميز والمنافسة

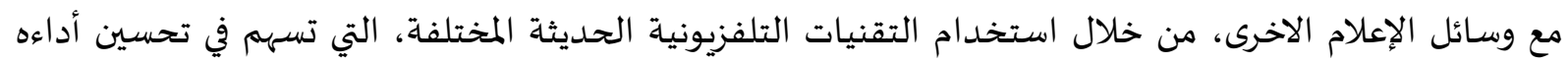
وزيادة متابعته من قبل الجمهور.

وتعد القنوات التلفزيونية أحد مظاهر التطور الحديث التي باتت تتنافس في شتى مجالات الحياة اليومية

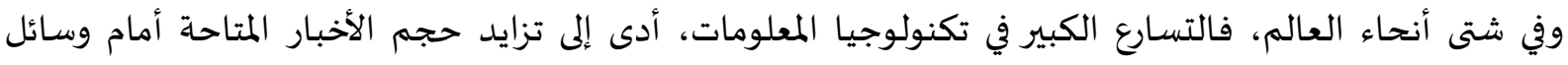

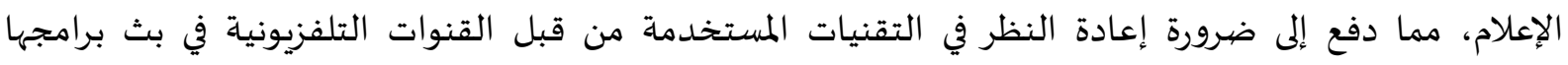
المختلفة (عبد النبي، 2014).

لقد تطورت تكنولوجيا الاتصال في إنتاج البرامج التلفزيونية حديثاً بصيورة متسارعة وخاصة في مجال

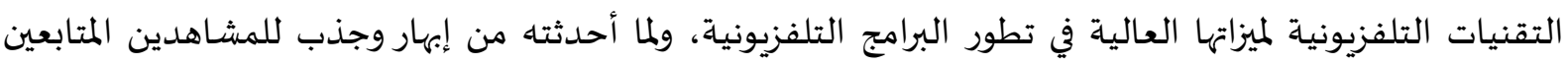

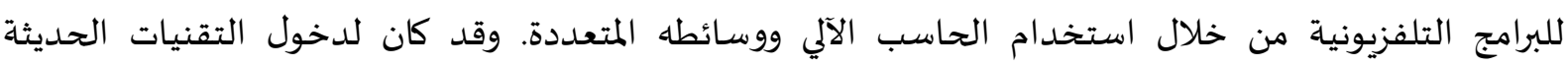

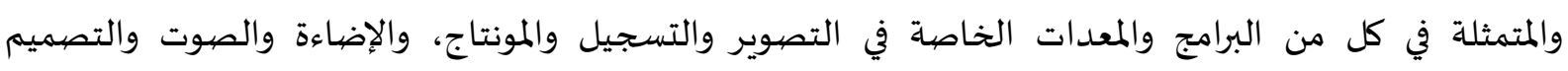
(الجرافيك)، والانفوجرفيك والصورة والنصوص المقدمة التي باتت أدوات لا بد من المن اقتنائها من أجل تحسين

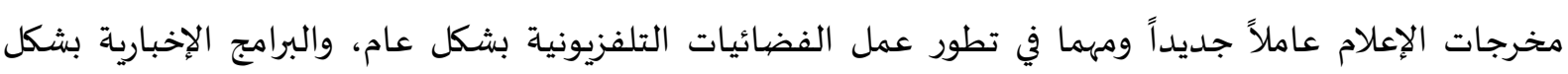

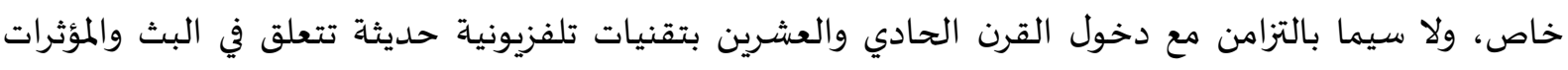

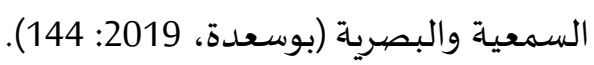
تتميز وسائل الإعلام الحديثة عن وسائل الإعلام التقليدية، في خاصية التفاعلية بين المرسل والمستقبل،

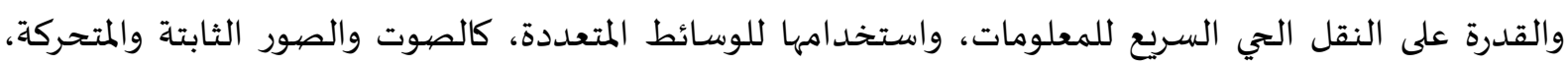

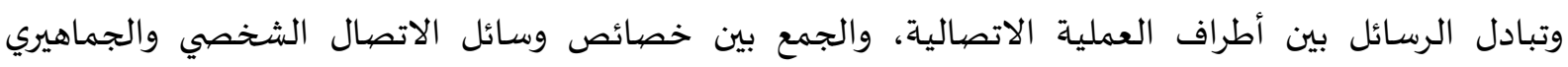
والكونية والزمانية في أن واحد.

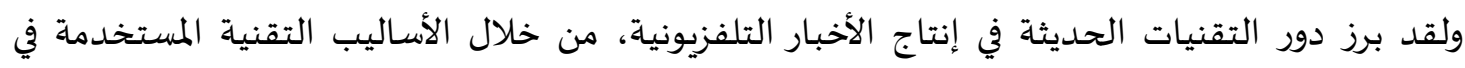

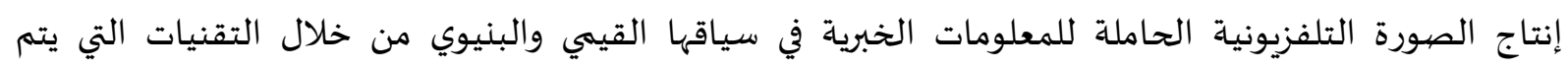
استعمالها لترويج صورة تلفزيونية تعمل على نشر وترسيخ معلومة خبرية معينة لدى جمهور المتلقين مع نقلها

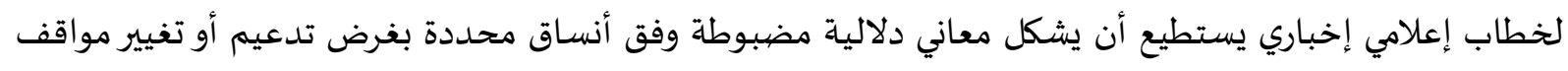

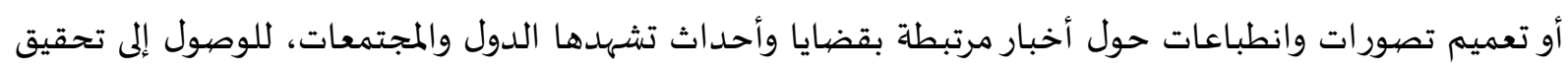

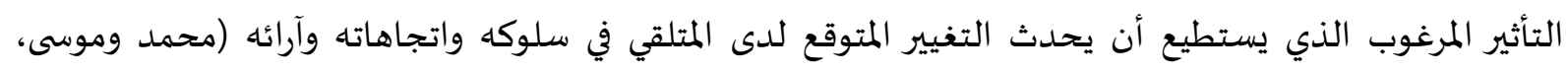


وانطلاقاً مما سبق تسعى الدراسة إلى التعريف بالتقنيات التلفزيونية الحديثة وإبراز دورها في زيادة متابعة

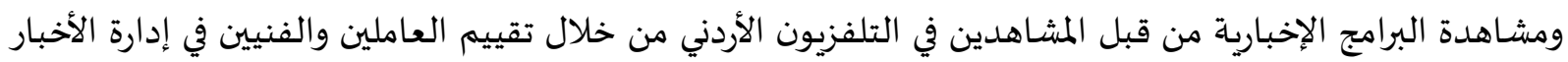
في التلفزيون الأردني.

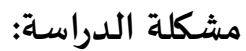

باتت التقنيات التلفزيونية الحديثة من أهم الأهداف التي تسعى القنوات التلفزيونية لتبنيها لما لها من فائدة

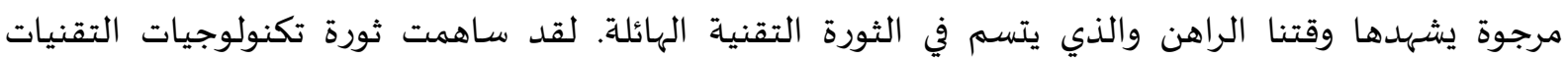

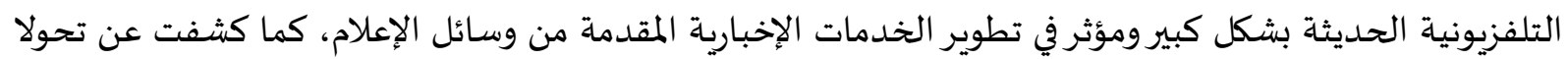

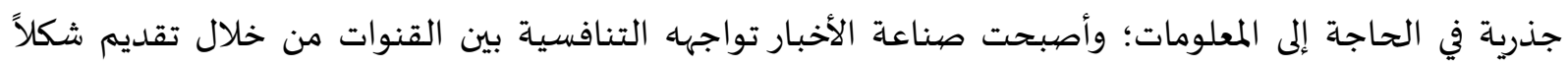

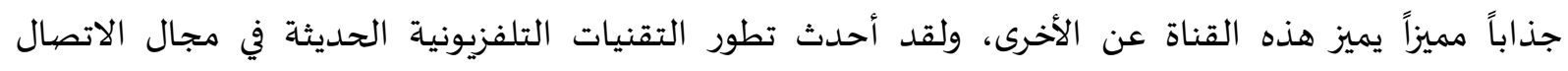

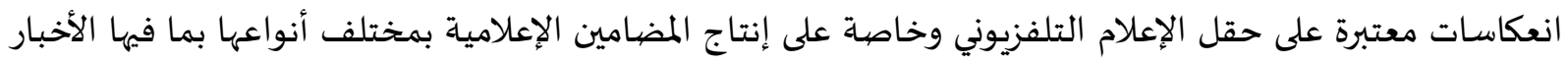

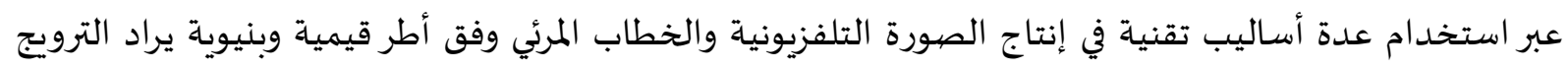

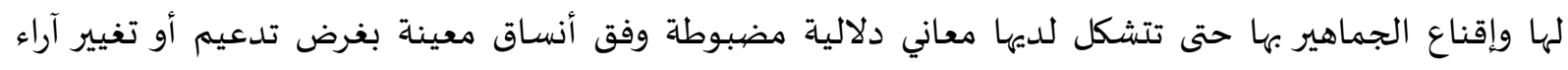

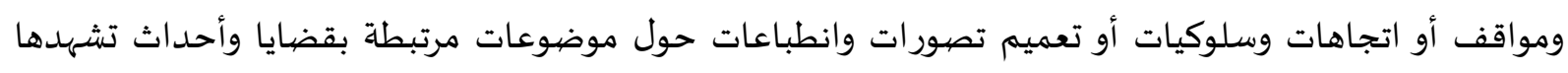

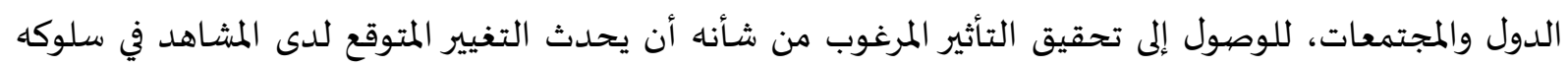

واتجاهاته وآرائه.

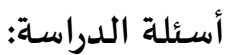

بناء على ما سبق؛ تتحدد مشكلة الدراسة في التساؤلات الآتية: 1- ما التقنيات التلفزيونية الحديثة المستخدمة في البرامج والنشرات الإخبارية في التلفزيون الأردني من وجهات الاتية

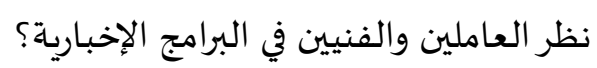

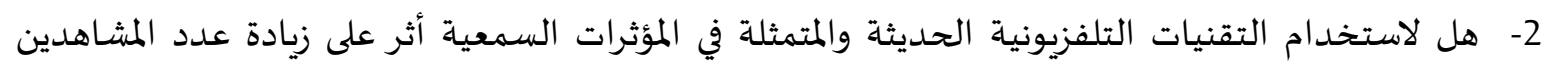

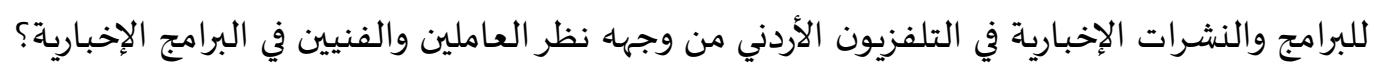

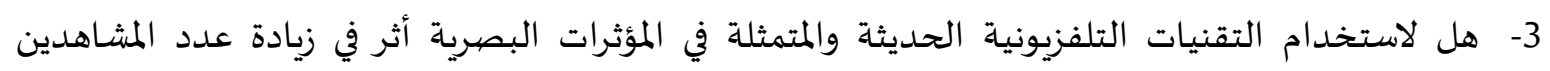

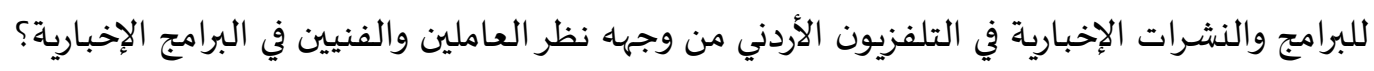
4- كيف تساهم التقنيات التلفزيونية الحديثة المستخدمة في البرامج والنشرات الإخبارية في التلفزيون الأردني في الإني

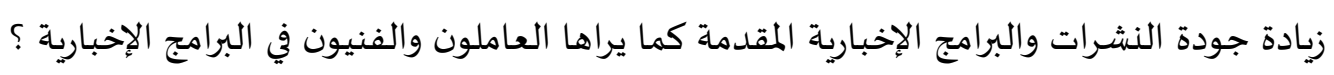

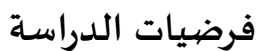

1- الفرضية الرئيسة الأولى: لا يوجد أثر ذو دلالة إحصائية عند مستوى الدلالة (10.05) لاستخدام التقنيات

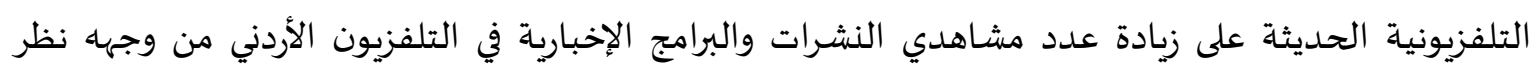

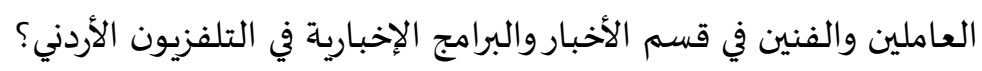
2- الفرضية الفرعية الأولى: لا يوجد أثر ذو دلالة إحصائية عند مستوى الدلالة (0.05>0.

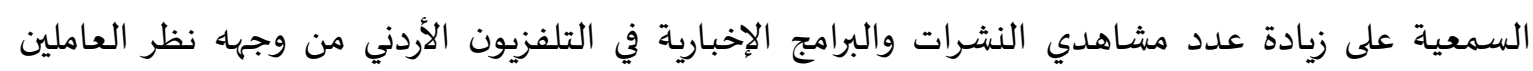

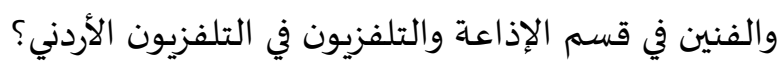


3- الفرضية الفرعية الثانية: لا يوجد أثر ذو دلالة إحصائية عند مستوى الدلالة (0.05) لاستخدام المؤثرات

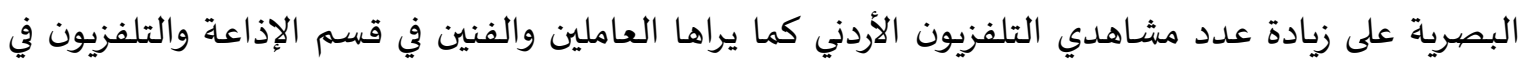

التلفزيون الأردني؟

$$
\text { أهداف الدراسة }
$$

هدفت الدراسة إلى التعرف على التقنيات التلفزيونية الحديثة المستخدمة في البرامج والنشرات الإخبارية في التلفزيون الأردني وأثرها على زيادة متابعة هذه البرامج من وجهة نظر الفنيين والعاملين في البرامج الإخبارية بالتلفزيون الأردني.

$$
\text { ويتفرع من الهدف الرئيسي الأهداف الفرعية الآتية: }
$$

1- - التعرف على أثر استخدام المؤثرات البصرية المستخدمة في البرامج والنشرات الإخبارية في التلفزيون الأردني

$$
\text { في زيادة أعداد مشاهدي البرامج. }
$$

2- التعرف على أثر استخدام المؤثرات السمعية المستخدمة في البرامج والنشرات الإخبارية في التلفزيون الأردني

$$
\text { في زيادة أعداد مشاهدي البرامج. }
$$

3- التعرف على مدى إسهام التقنيات التلفزيونية في زيادة جودة البرامج والنشرات الإخبارية المتابعة في التلفزيون

$$
\text { الأردني. }
$$

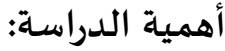

تنبع أهمية الدراسة النظرية من خلال التعرف على ما تقدمه التقنيات التلفزيونية الحديثة من دعم لعمل

$$
\text { القنوات الفضائية ومساهمة في زيادة عدد المشاهدين لهذه القنوات التهات التلفزيونية. ويؤمل الباحثان الآتي: }
$$

- أن تقدم نتائج الدراسة توصيات مناسبة لمؤسسات التلفزيون في المنطقة العربية وللمهتمين من أكاديميين ومراكز

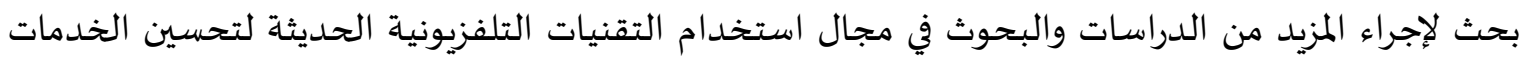

$$
\text { التي تقدمها هذه المحطات ولزيادة عدد المشاهدين. }
$$

كما يأمل الباحثان، أن تقدم الدراسة توصيات علمية وعملية لتطوير البرامج والنشرات والبرامج الإخبارية في

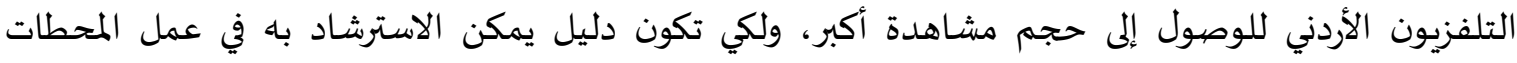

$$
\text { التلفزيونية الأردنية الاخرى. }
$$

تقتصر هذه الدراسة على الحدود التالية:

الحدود الموضيوعية: استخدام التقنيات التلفزيونية الحديثة وأثرها على زيادة متابعة مشاهدة البرامج

الإخبارية.

الحدود البشرية: العاملين والفنين في دائرة البرامج الإخبارية في التلفزيون الأردني.

الحدود الجفرافية: التلفزيون الأردني في المملكة الأردنية الهاشمياة.

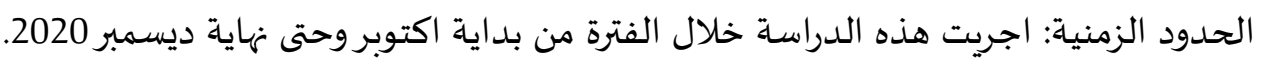


- تأثير: تعرف موسوعة علوم الإعلام والاتصال الأثر بأنه نتيجة الفعل الذي ظهر جراء مؤثر ما (ثمار، 2007: 21)

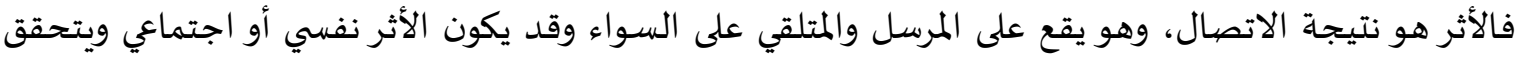

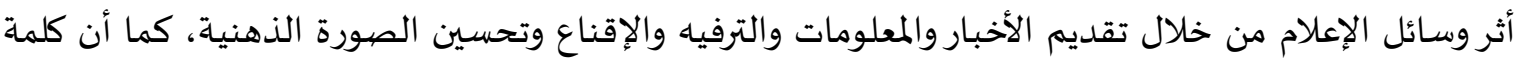

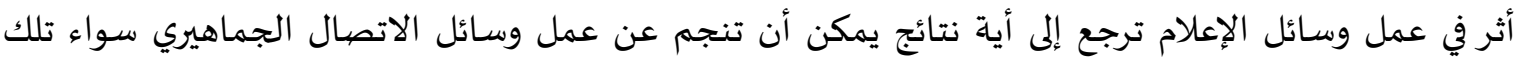

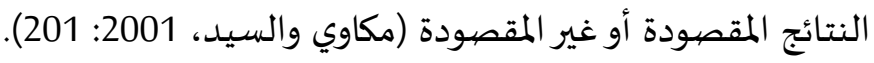

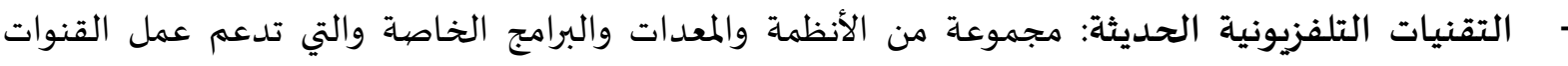
الفضائية والتي تسعى إلى تحسين جودة الصيوت والصورة من خلال منظومة عمل متكاملة (الجمال، 2013:

O ويقصد بها إجرائيا: بأهها كل ما يتم استخدامه من قبل التلفزيون الأردني من معدات وبرمجيات وأنظمة تهدف

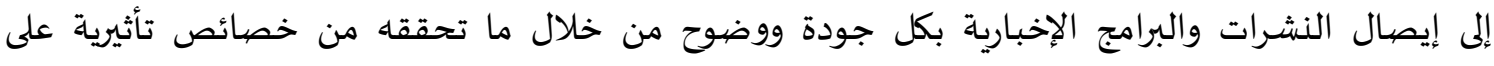

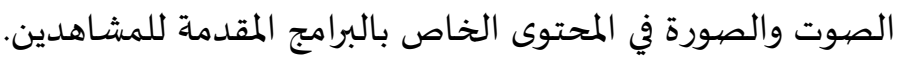

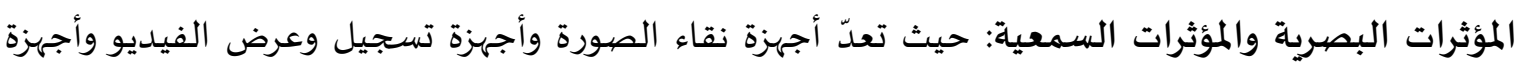

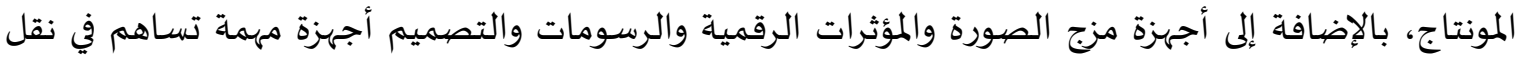

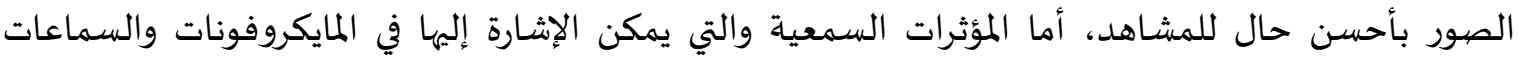

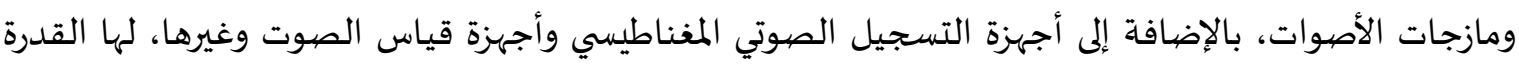

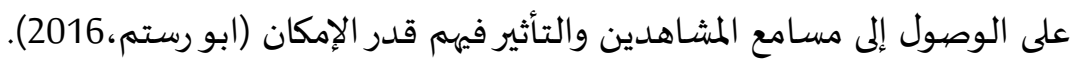

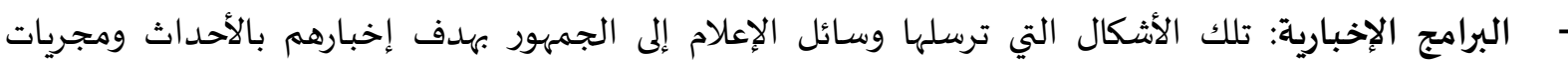

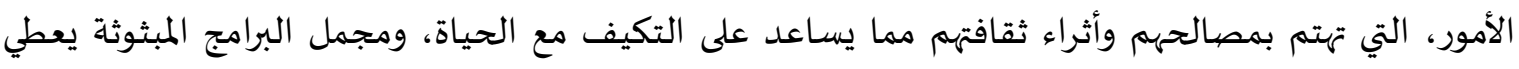

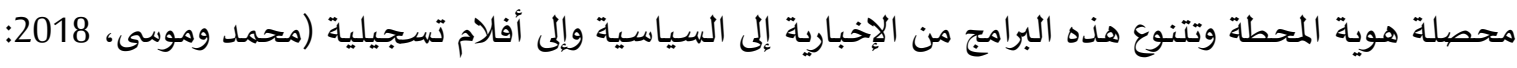

O متعرف إجرائيا على أهها: البرامج التلفزيونية الإخبارية التي تبث من خلال القنوات الفضائية الأردنية والتي

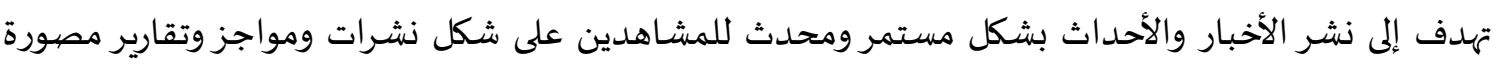

$$
\text { (أفلام إخبارية وأرقام ورسومات إيضاحية). }
$$

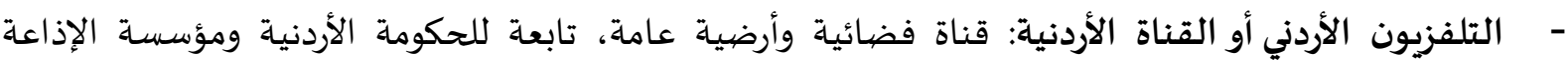

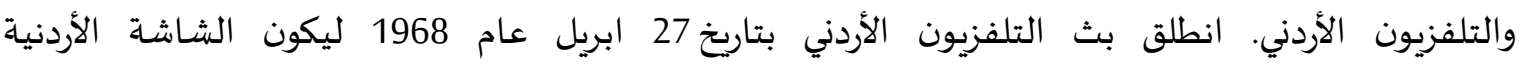

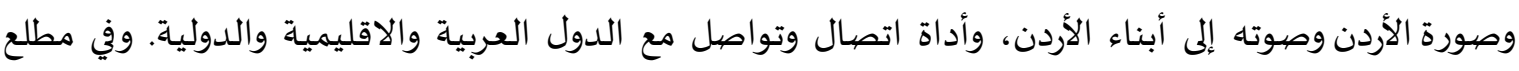

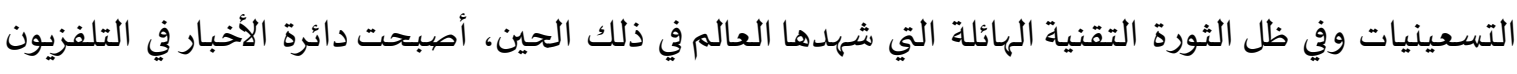

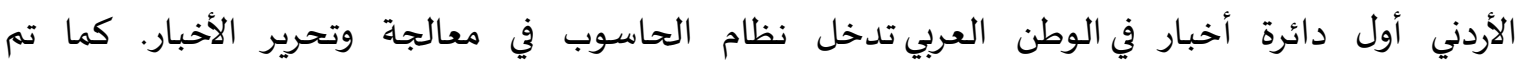

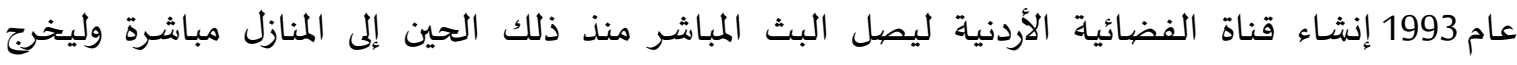

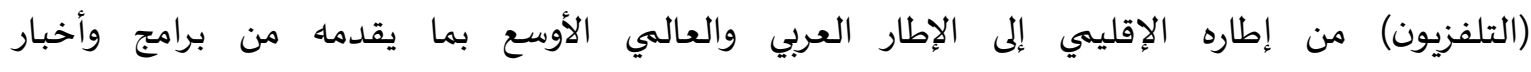

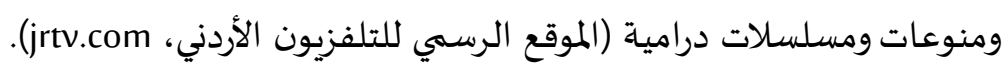


2- الأدب النظري: التقنيات التلفزيونية الحـديثة.

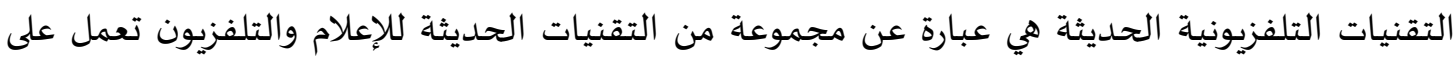

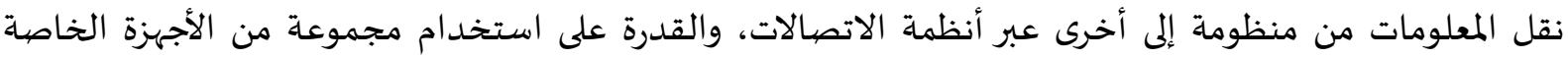

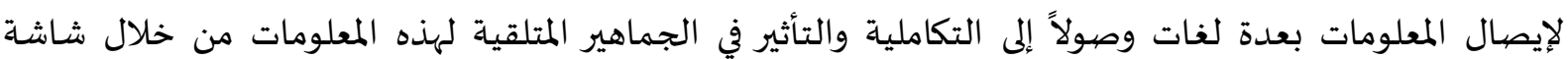
التلفزيون (ابراهيم، 2017: 246).

يعد استخدام التقنيات التلفزيونية الحديثة في تغطية النشرات الإخبارية مهمة أسـاسية في صناعة الخبر

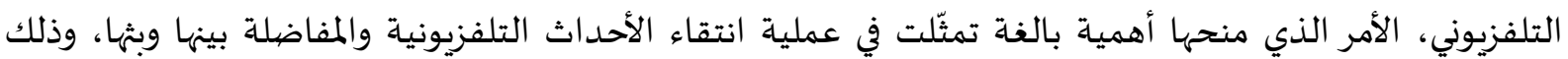

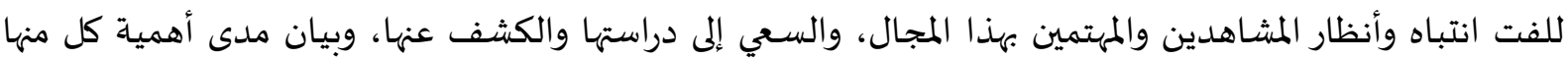

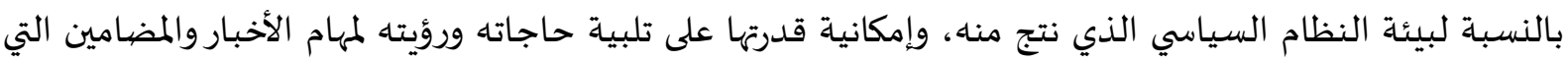
تحملها، والمعايير التي تعتمد للتغطيات الإخبارية، ووظيفة أجهزة الإعلام المرئي.

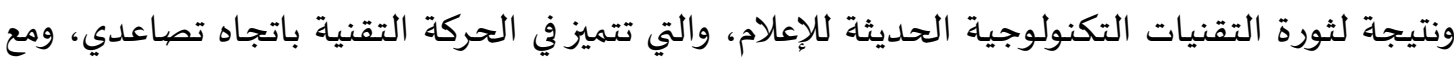

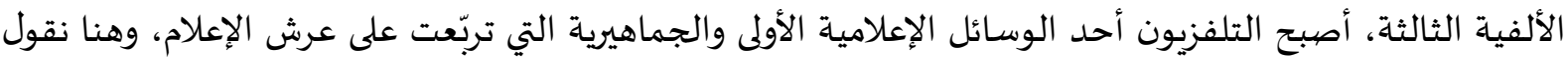

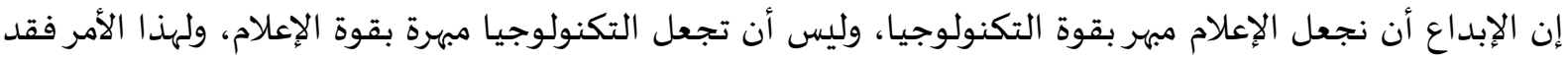

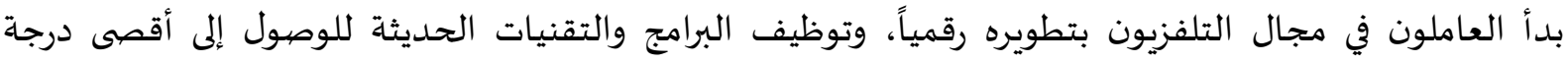

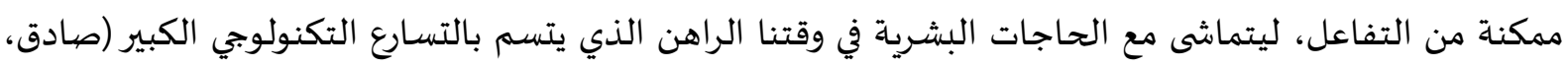

(246:2008

وعليه تعتبر وسائل الإعلام والاتصال الحديثة ثمرة للمعرفة العلمية ونتاج للثورة التقنية الهائلة التي

يشهدها العالم، حيث أثرت هذه الثورة على الجماهير بمختلف أعراقهم، ومن هنا فإن ما يشهده العالم ككل من ثورة معلوماتية وتكنولوجيا أقمار الاتصالات والحواسيب الإعلامية، بالإضافة إلى تطور في استخدام تقنيات الاتصال الحديثة جعلت العالم قرية كونية صغيرة، وتلاشت محدودية المكان والزمان، وذلك لما تنتجاه هذه التقنيات من اندماج وارتباط العالم في منظومة واحدة تتصف بالتماسك (إبراهيم، 2017: 97).

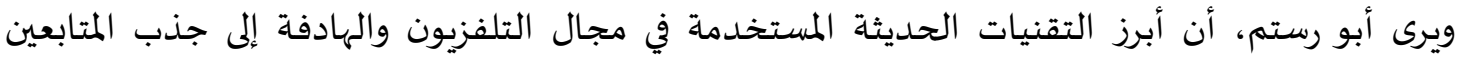
وزيادة أعدادهم، تتمثل بما تستخدمه إدارة القنوات الفضائية من برمجيات ومعدات خاصةة، بهدف إخراج العمل الإعلامي بأعلى مستويات الجودة وذلك لنقل كل ما هو جديد من خلال هذه التقنيات. كما أن أهم هذه التقنيات إدهات

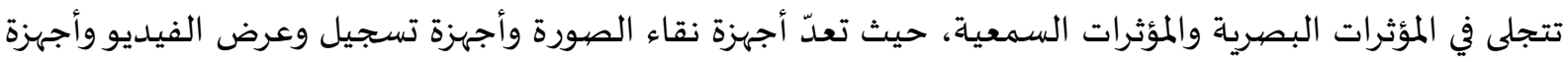
المونتاج، بالإضافة إلى أجهزة مزج الصورة والمؤثرات الرقمية والرسومات والتصميم أجهزة مهمة تساهم في نقل

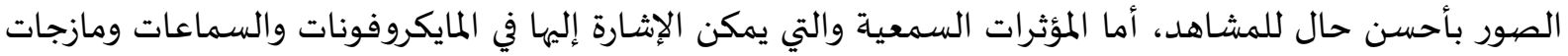
الأصوات، بالإضافة إلى أجهزة التسجيل الصوتي المغناطيسي وأجهزة قياس الصهوت وغيرها، لها القدرة على الوصهول

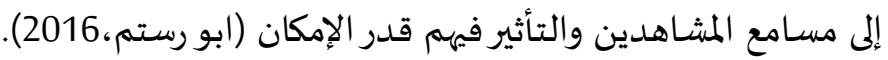

التقنيات الحديثة المستخدمة في إنتاج الأخبار التلفزيونية:

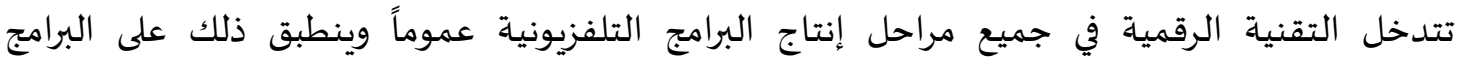
الإخبارية، باعتبارها أحد أشكال البرامج التلفزيونية، ويبدأ استخدام التقنية من البث ومن هذه البعاج التقنية عملية

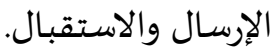


أولاً البث التلفزيوني المباشر لقد حظيت الأخبار التلفزيونية بتطورات هائلة في أساليب إنتاجها بفعل استخدام

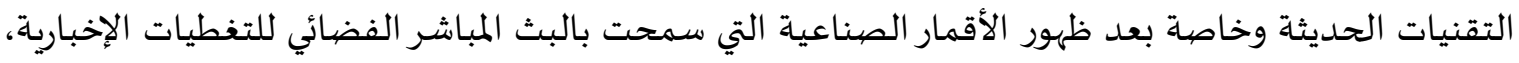

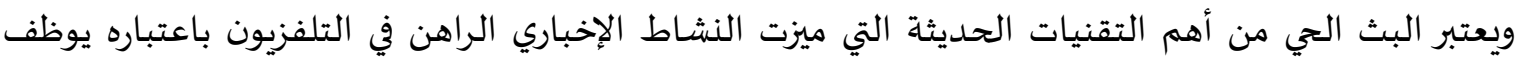

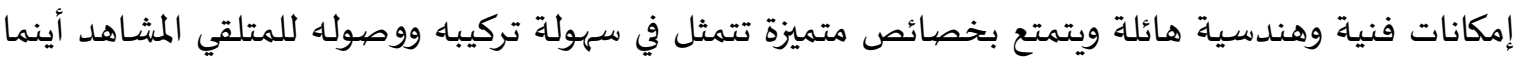

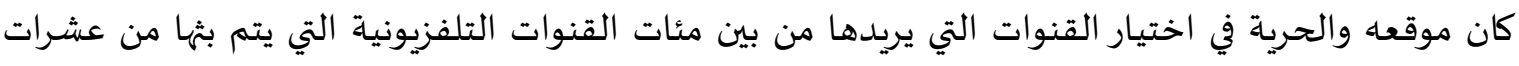

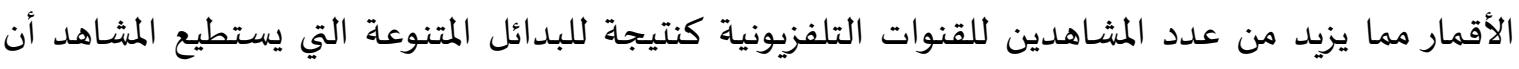

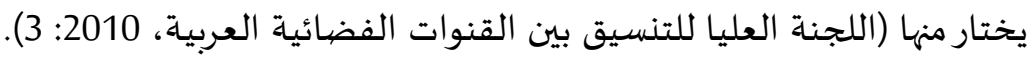

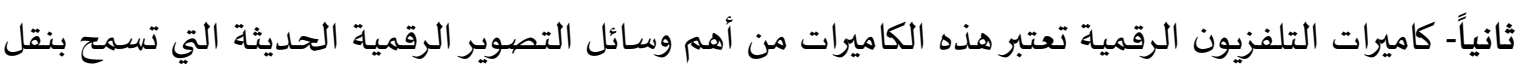
الأحداث والوقائع عبر الصوت والصورة سواء بطريقة مباشرة (Live) من داخل الاستوديو أو خارجه أو تسجلها

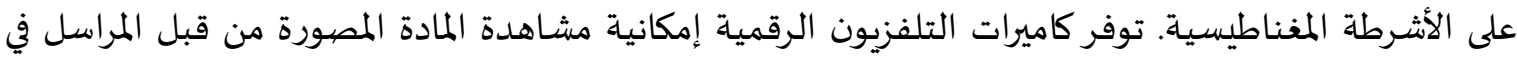

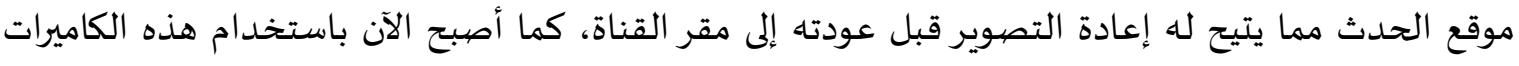

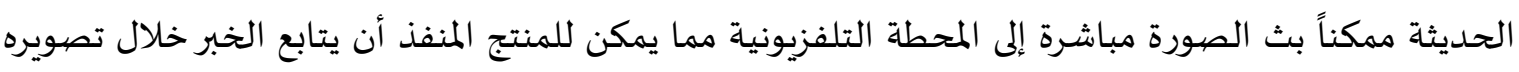

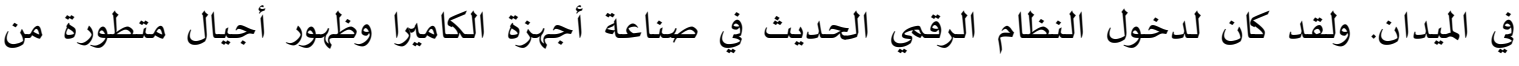

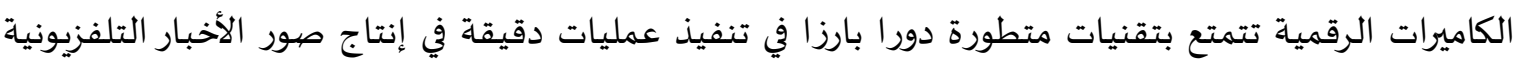
وهو ما ساعد الجمهور على متابعة الحداث مباشرة وبالتالي زيادة اعداد المشاهدين (معوض وبركات، 2015:

ثالثاً- شرائط التسجيل الرقمية قبل دخول التقنيات الحديثة في إنتاج الأخبار التلفزيونية كانت عملية تسجيلها

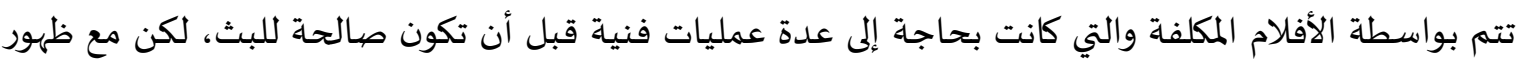
شرائط الفيديو الرقمية وتقنيات التسجيل والتخزين المتطورة أصبحت تغطية الأحداث تتم بسهولة وبشكل

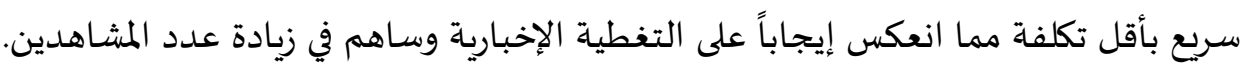

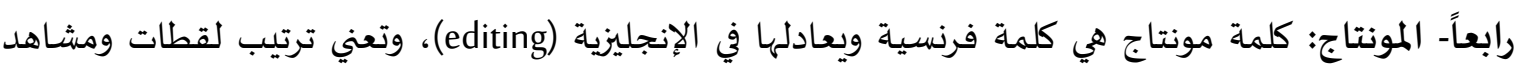

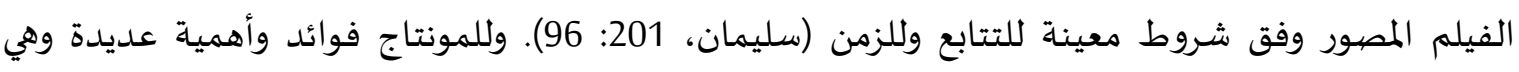
حذف الأجزاء الزائدة من المشاهد، تصحيح أخطاء التصوير أن أمكن، خلق تأثيرات وبيئات وأشكال على الواقع فئح

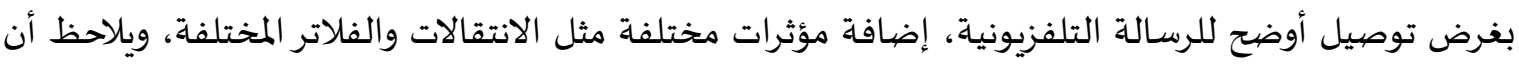

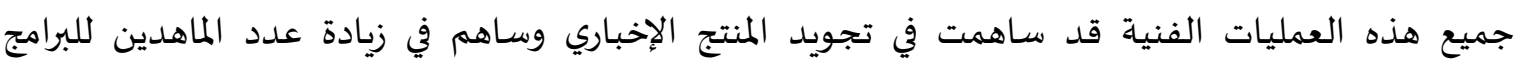
الإخباريـة. - خامساً الإضاءة: تستخدم الإضاءة لأغراض تقنية وجمالياً، أما الأغراض التقنية فهي إضاءة المنظر أمام الكاميرا

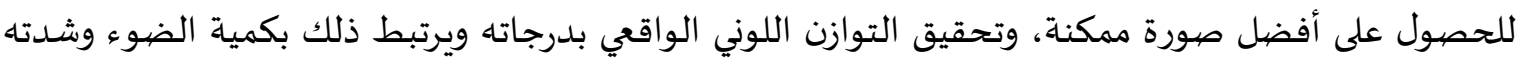

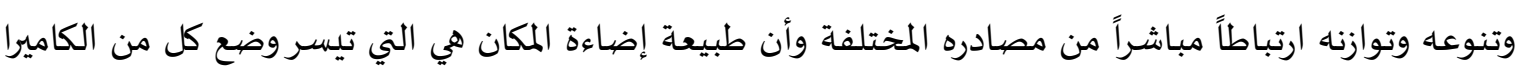

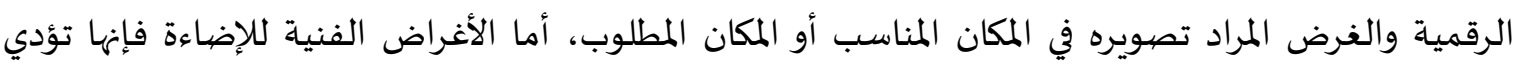

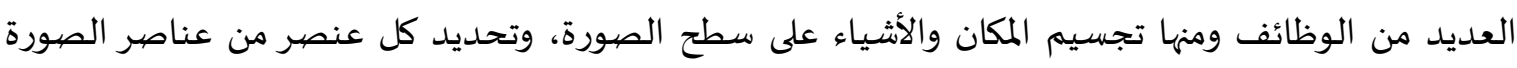

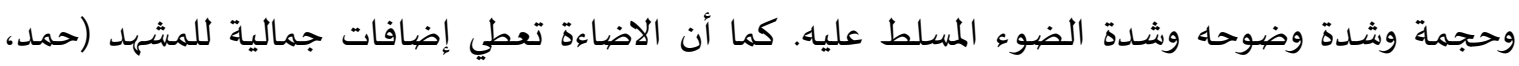

2018: 156 - 155)

سادساً- الصهوت: كان تسجيل الصوت أو بثه يعتمد على نظام صوتي يبدأ بالمايكروفون ثم أجهزة التحكم

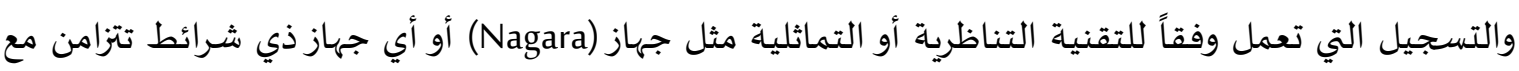


الكاميرا، وعلى الرغم من جودة الصيوت بواسطة تلك الأجهزة إلا أهها لا تخلو من التشويش، خاصة إذا تم نقل

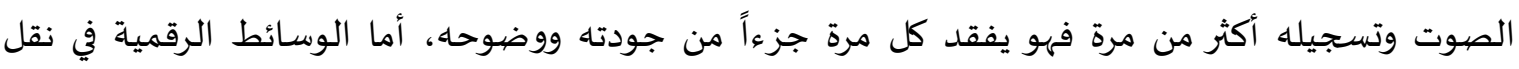

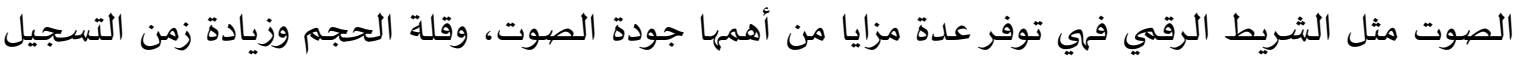

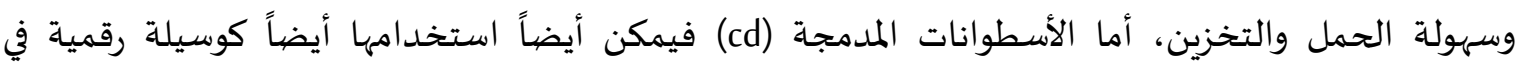

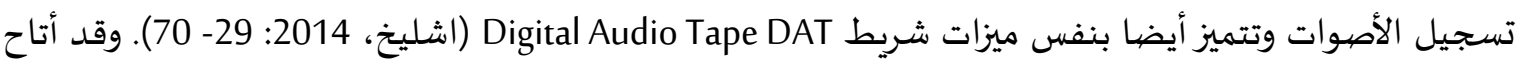
استخدام الحاسوب في المجال الصيوتي إمكانات متعددة في سهولة إدخال الأصهوات ومزجها، فمن خلفيل خلال

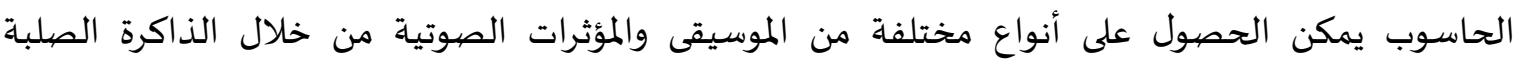

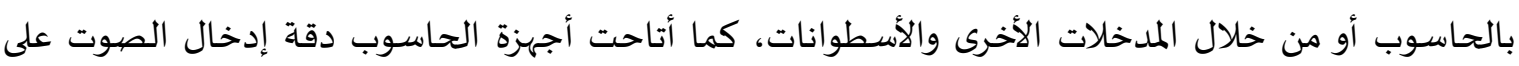
الصورة الدوبلاج. سابعاً- التصميم (الجرافيك) هناك برامج بالحاسوب تعمل على تصميم الأشكال والرسوم والخلفيات والشعارات

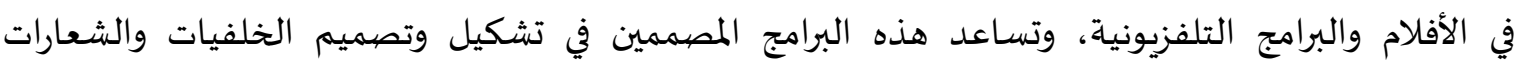

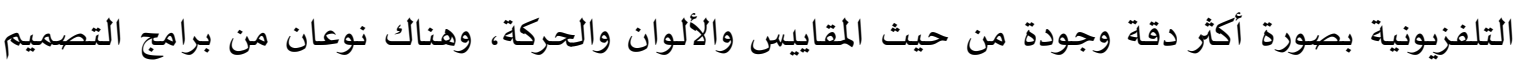

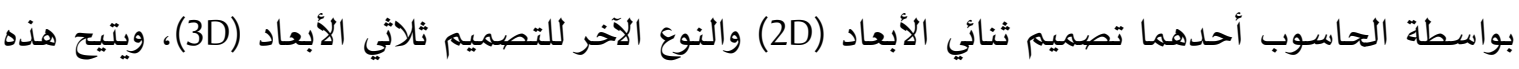

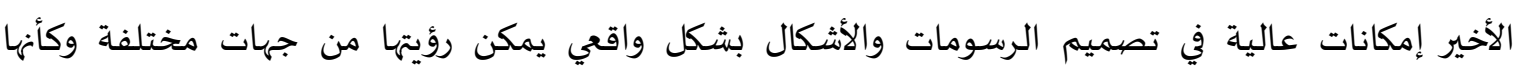

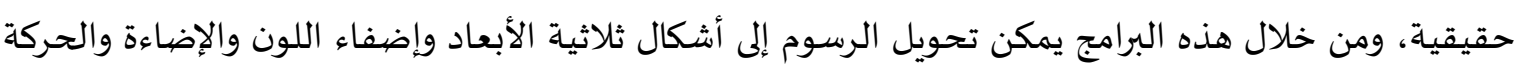

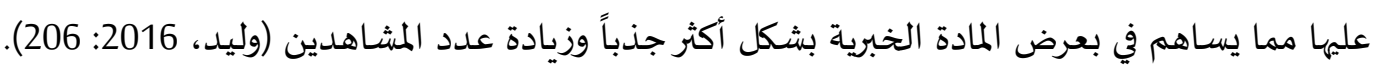

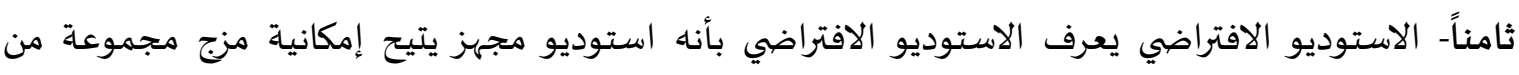

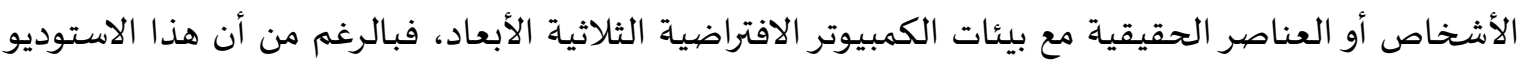

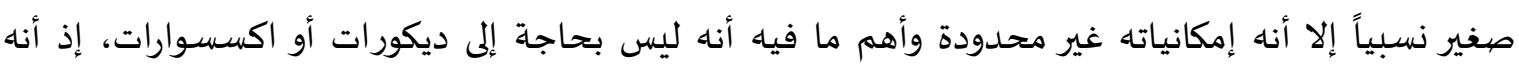

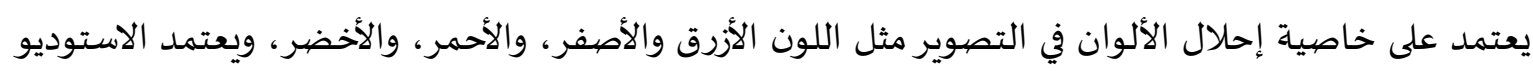

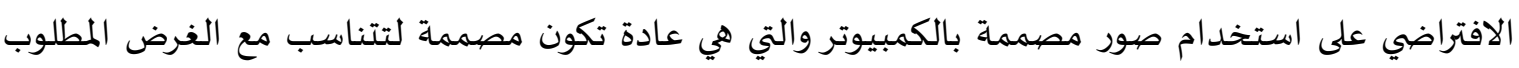

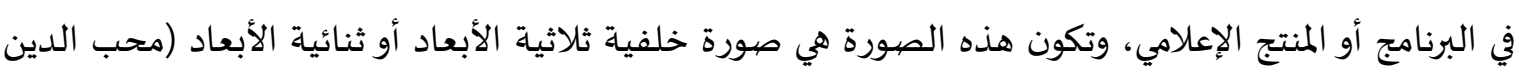
واخرون، 2011: 148- 149). تاسعاً- الكروما هو إضافة صورة أو جزء معين منها إلى صورة أخرى للإيحاء للمشاهد بأن الصهورتين عبارة عن

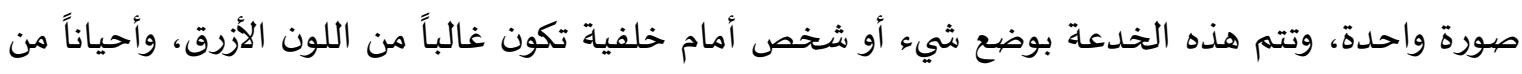

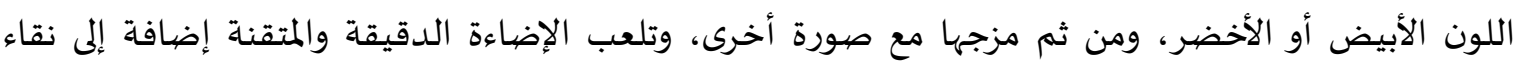

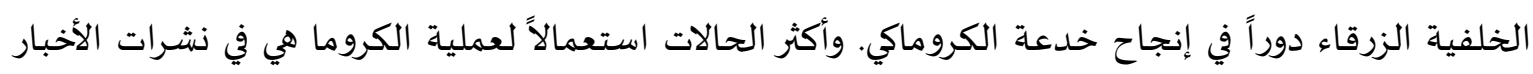

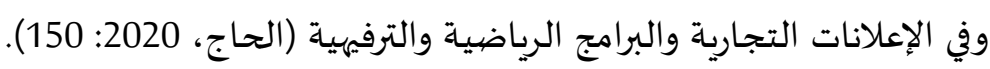

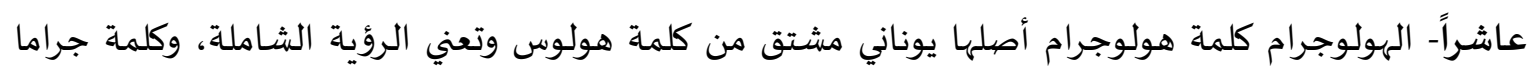

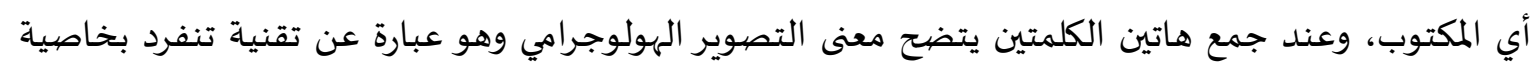

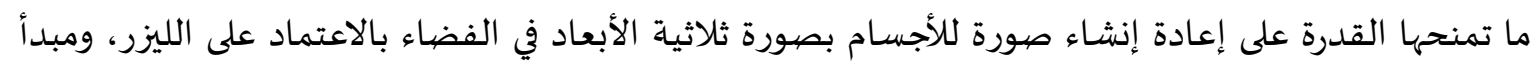

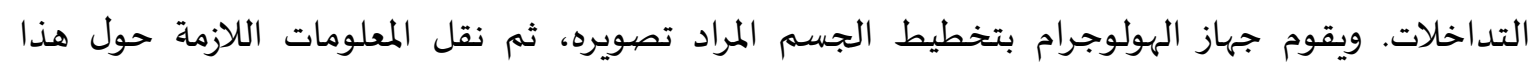

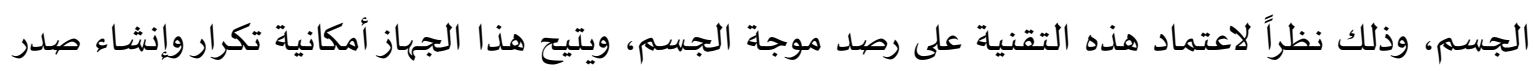

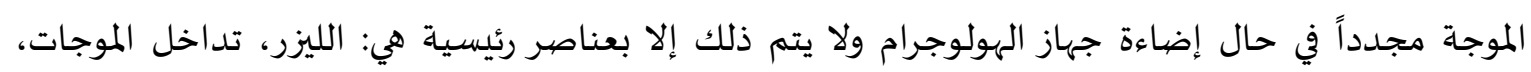

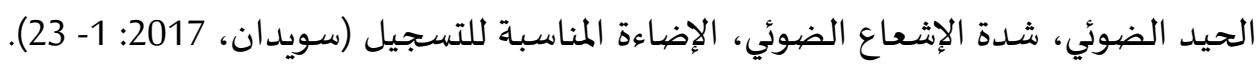




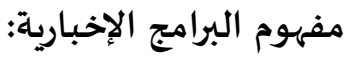

تعد النشرة الإخبارية من أولى أشكال البرامج الإخبارية ويقصد بهاريا المعلومات أو الآراء حول حدث محلي أو الماري

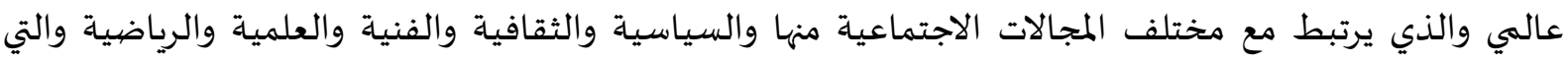

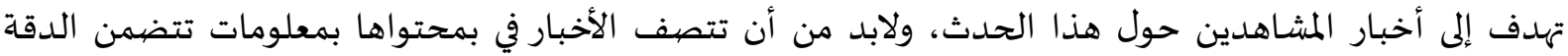
والتوازن والموضوعية وبصيغة واضحة وبسيطة. وتتضمن البرامج الإخبارية أشكال عدة منها:

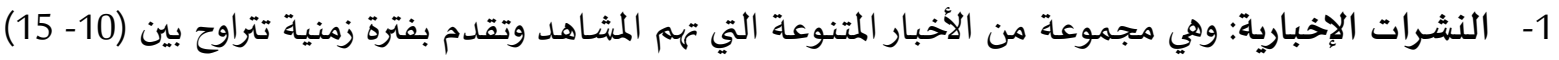
دقيقة وأكثر، وفي أوقات محددة في اليوم الواحد. وتعتبر النشرات الإخبارية إحدى صهور الإعلام والاتصال بالمشاهدين، وتعتمد على الصورة الثابتة والمتحركة والصوت وذلك بهدف إعطاء مصداقية أكثر في نقل الخبر.

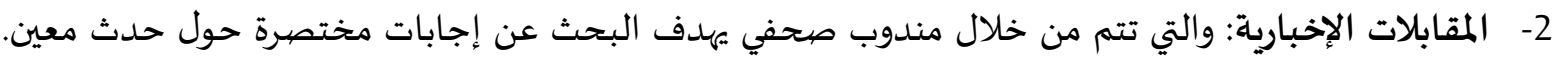
وتنقسم المقابلة إلى مقابلة إخبارية ومقابلة شخصياة، وتعتمد على عدد من الأساليب المحدددة.

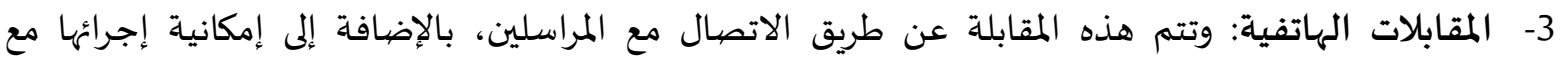
المسؤولين داخل الدولة وخارجها حول قضية ما.

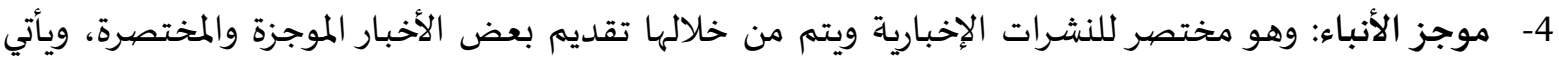

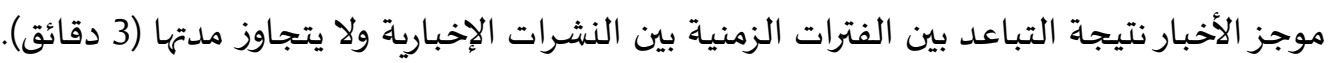

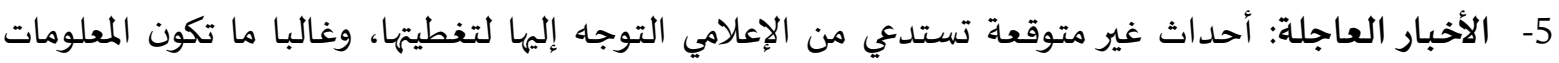
المتوافرة عن تلك الأخبار العاجلة مقتضببة. 6- الربط المباشر التلفزيوني: وهو ربط بين أكثر من مصدر ومن مواقع مختلفة لتغطية خبر او حدث معين بين

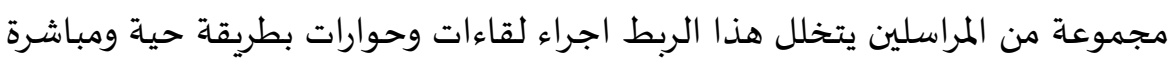

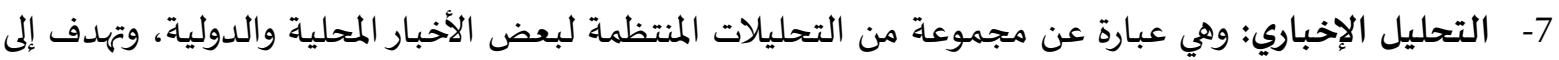
تقديم أخبار عميقة وموسعة للأخبار المعروضية.

8- التعليق الإذاعي: ويقصد بها التعبير عن الرأي من خلال اختيار موضهوع إخباري مهم لله أثر على المشاهدين.

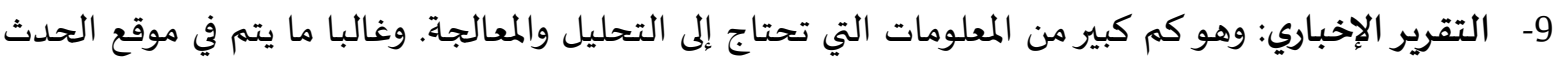

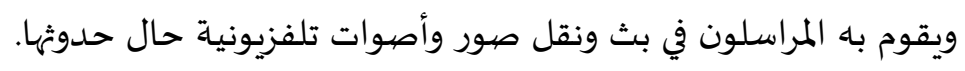

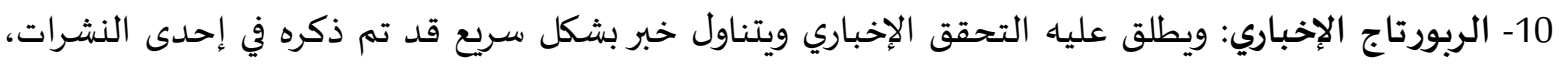
ويهدف إلى تقديم معلومات أكثر مدعمة بآراء.

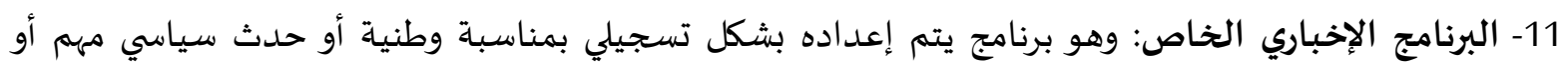
حدث معين ومدته تتراوح بين نصف ساعة وساعة الاعباء أو أكثر.

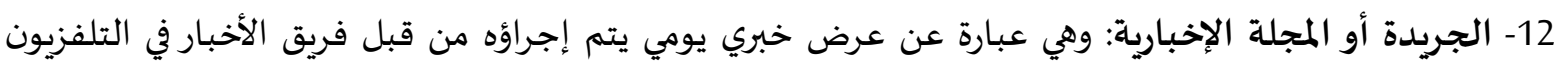

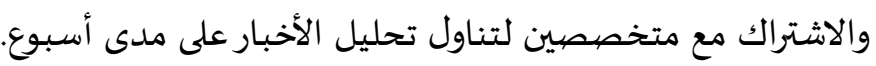

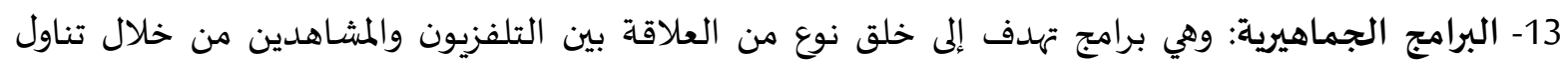

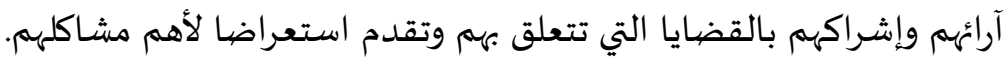

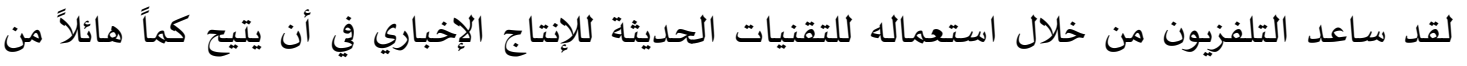

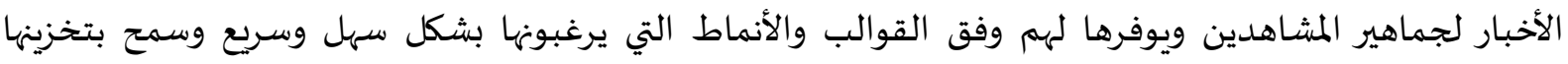


واسترجاعها وإعادة بثها إضافة إلى إعادة ترتيبها بسرعة فائقة، والأخبار التلفزيونية في جوهرها هي مواد سمعية بصرية

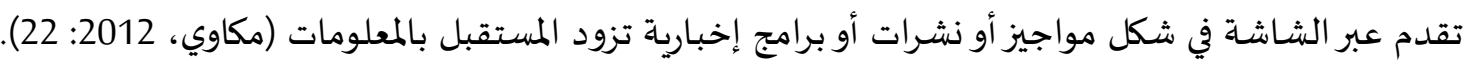

3- 2 - الدراسـات السابقة: - دراسة بو سعدة (2019)، سعت هذه الدراسة إلى إبراز دور التقنيات الحديثة في إنتاج الأخبار التلفزيونية

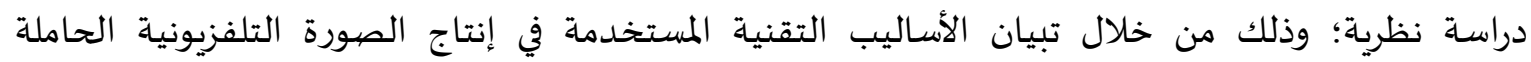

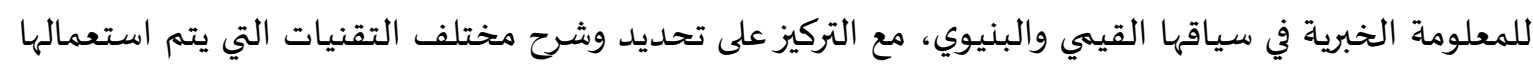
لترويج صورة تلفزيونية تعمل على نشر وترسيخ معلومة خبرية معينة لدى جمهور المتلقين. وأظهرت نتائج

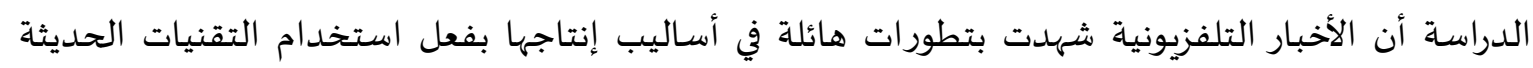

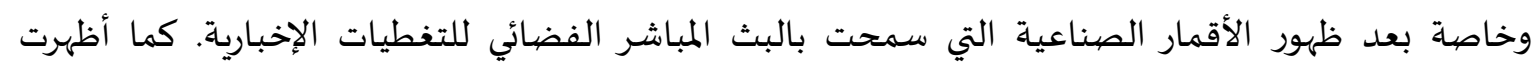
الدراسـة أن الدخول للنظام الرقي الحديث في صنعة أجهزة الكاميرا وظهور أجيال متطورة من الكاميرات

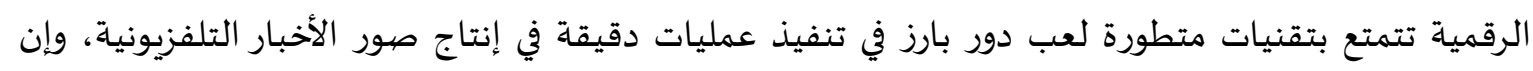

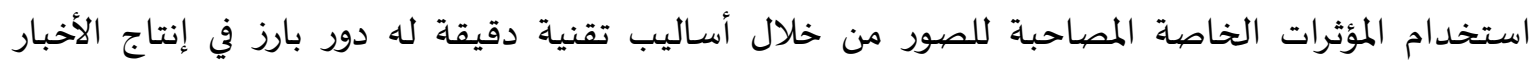

التلفزيونياة. دراسة الرمتي (2018)، هدفت هذه الدراسة التعرف على كيفية توظيف الإعلام الرقي في إنتاج البرامج

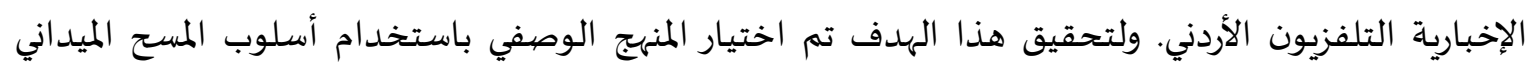

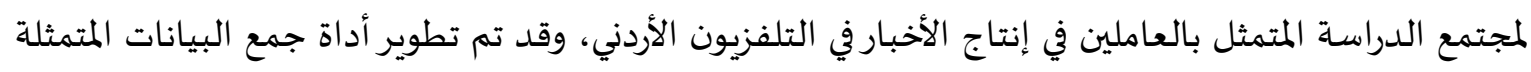

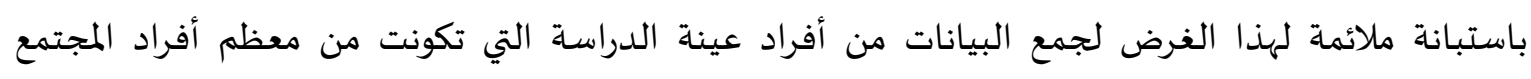

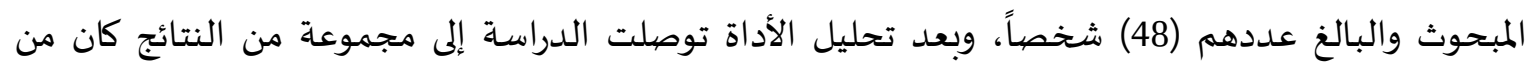

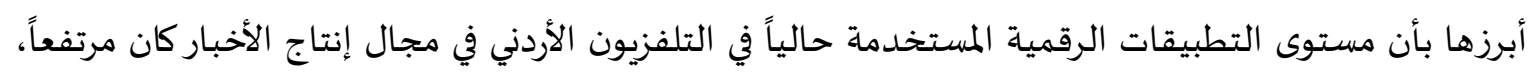

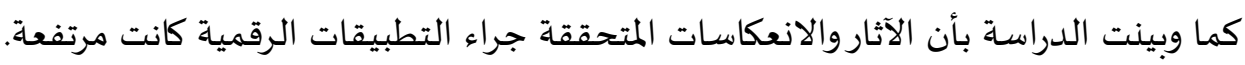
دراسة الزعبي (2017)، هدفت هذه الدراسة التعرف على تأثير الصيورة على المشاهد في التلفزيون الأردني من

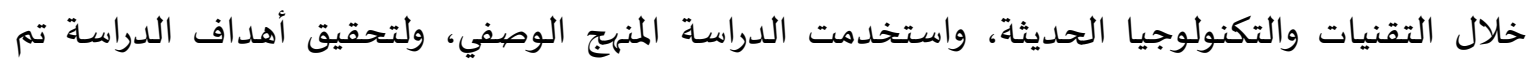

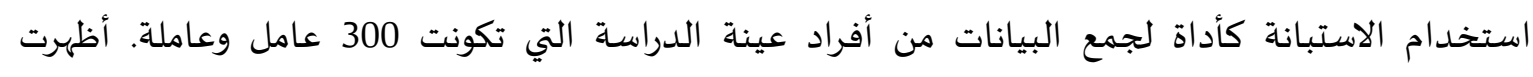

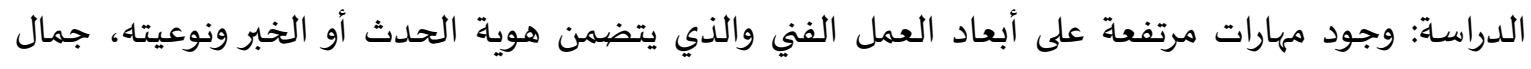

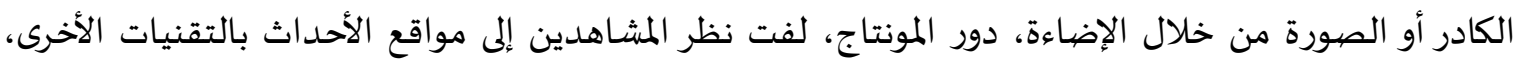

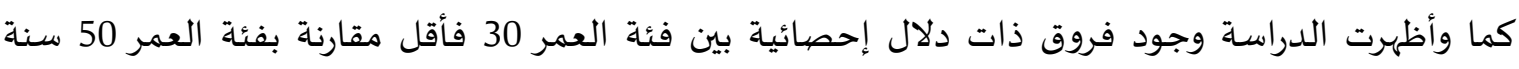

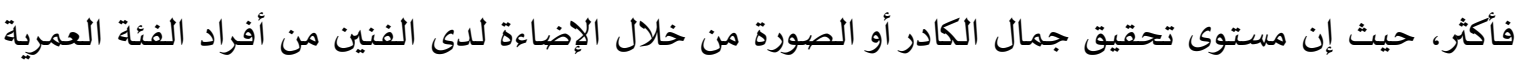

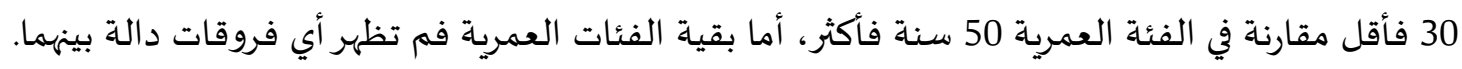
دراسة جمال الدين بوعزة (2015). هدفت هذه الدراسة إلى معرفة دور تكنولوجيا الاتصال الحديثة ومدى الفئه

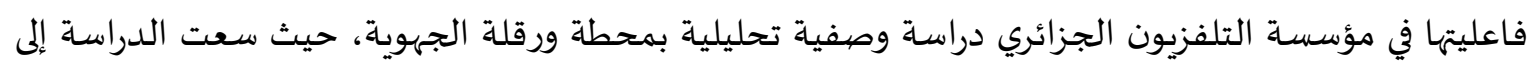

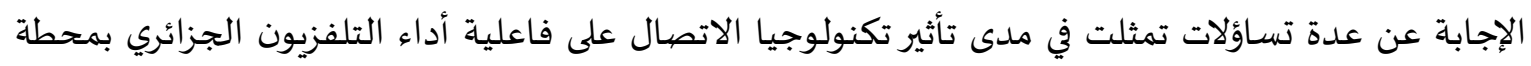

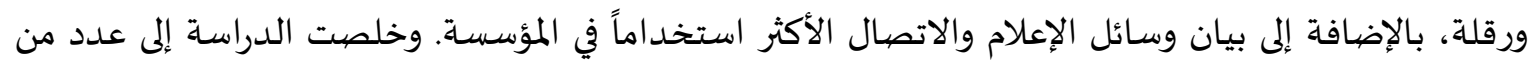

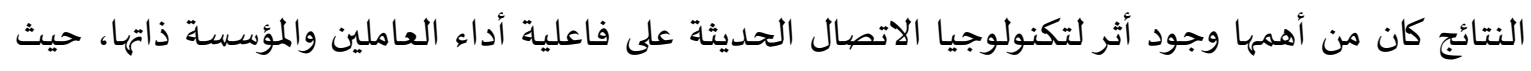
غيرت التجهيزات والمعدات بنسبة 80\% بتطوير أداء المؤسسة. في حين أظهرت نتائجها أيضا أن أنسائه العاملين في 


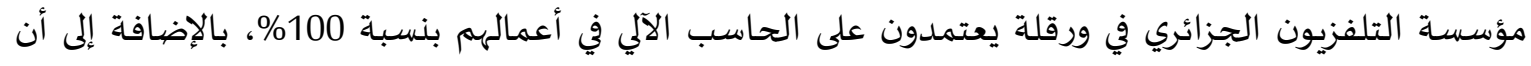

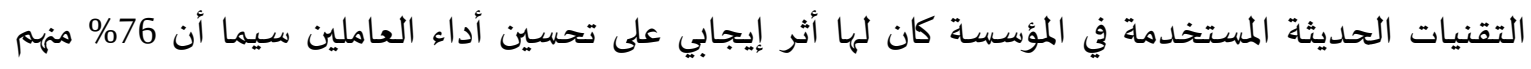
تلقوا دورات تدريبية خاصة في هذا المجال.

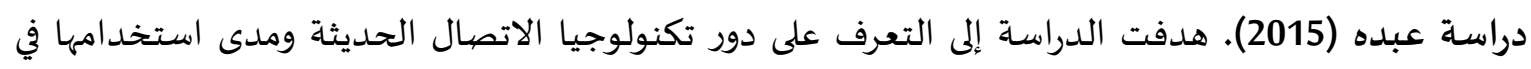

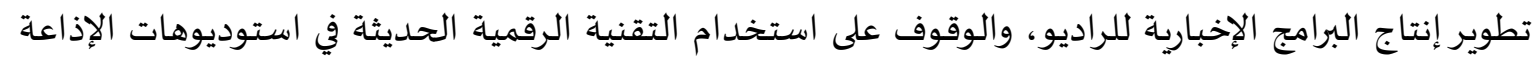

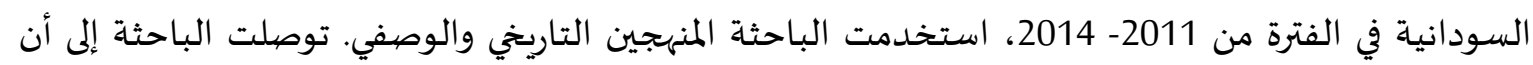

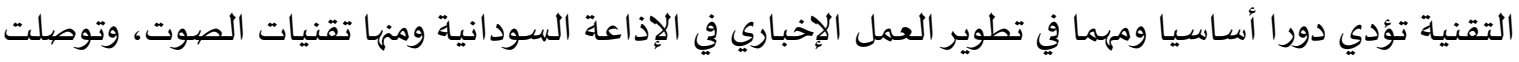

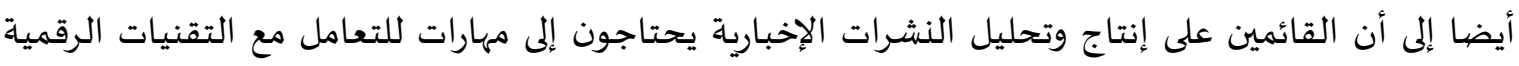

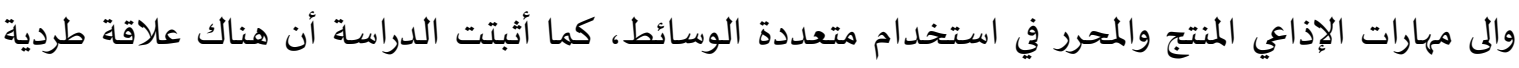

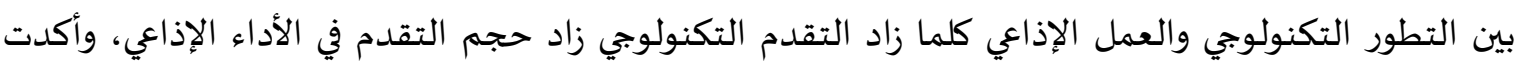

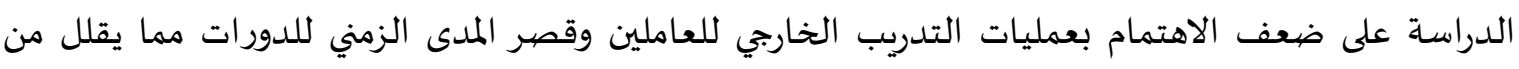

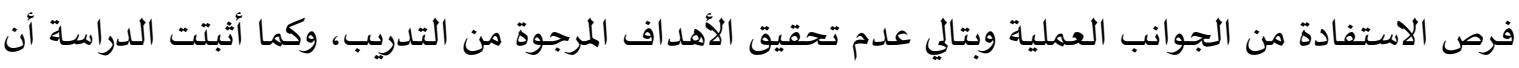

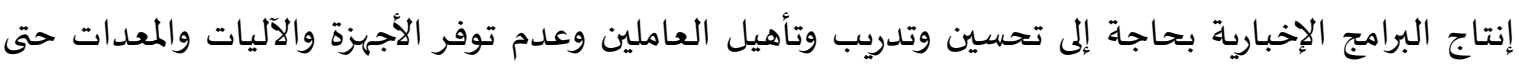
تكتمل فاعلية الإنتاج الإخباري. هدفت دراسـة. (Ellis, K.. 2014)، إلى بيان دور التقنيات الحديثة المتاحة في التلفزيونات الرقمية على تسهيل

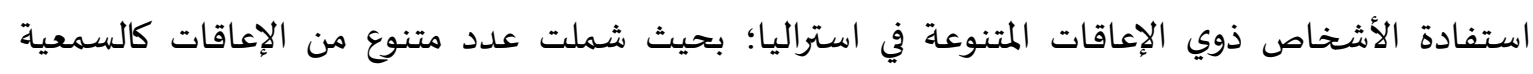

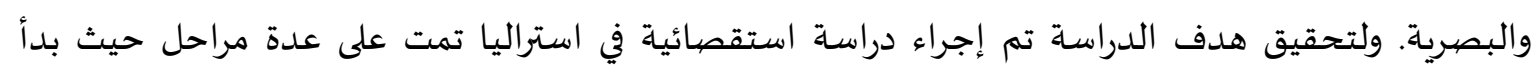
الباحث بإجراء مسحا شاملا لمنطقة الدراسة لتحديد الأشخاص المستهدفين ثم إجراء تحليل لمدىى إمكانية

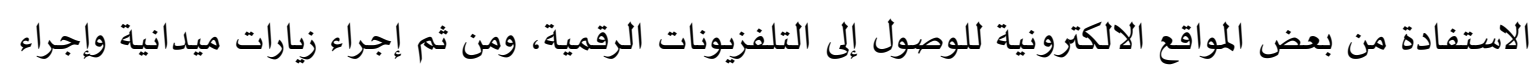

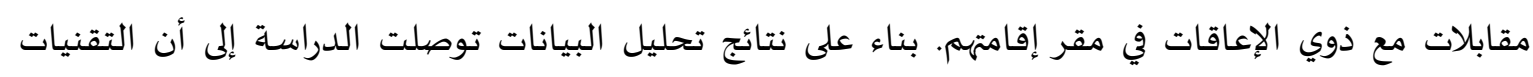

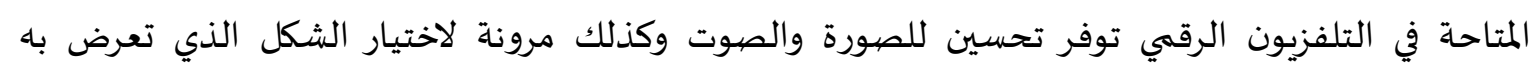

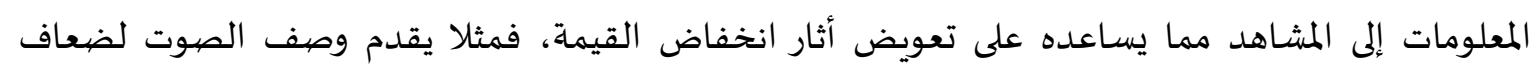

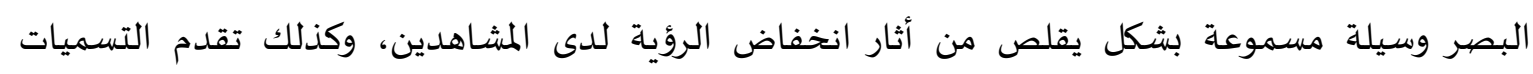

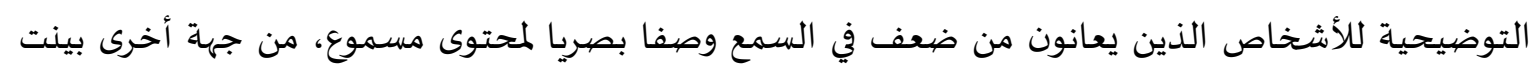

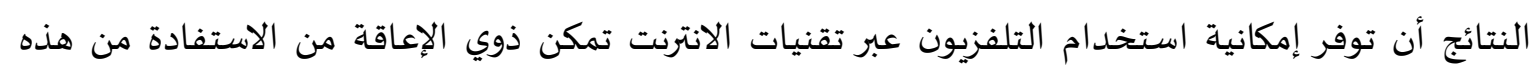
التقنيات في تعويض النقص الذي يعانون منها. دراسة (2012) Michael D. McNiven, Dean Krugman, Spencer F. Tinkham). هدفت هذه الدراسة

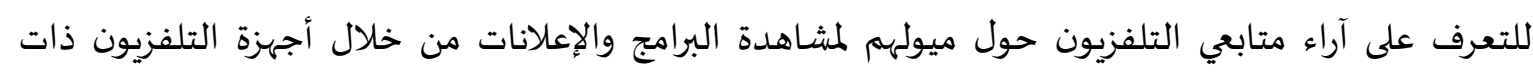

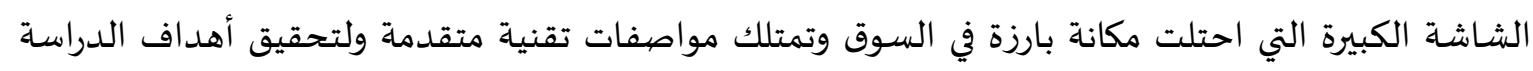
تم التركيز على مجموعات محددة من بلغت (36) مستجيبا وكذلك إجراء دراسة استقصائية عبر الانترنت

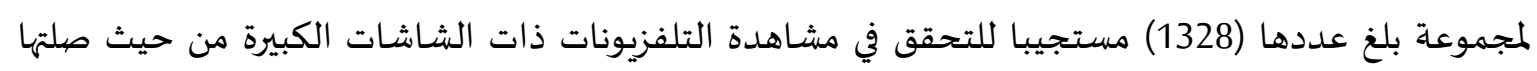

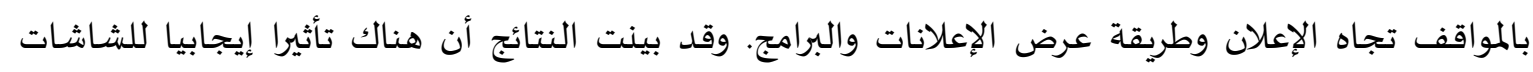

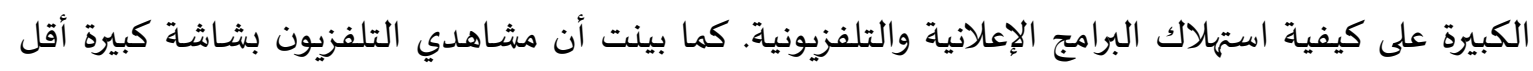

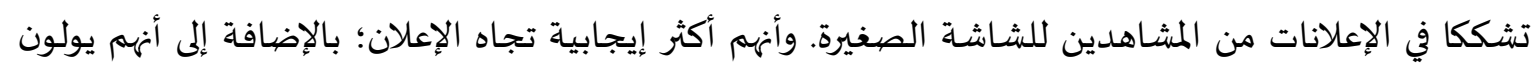

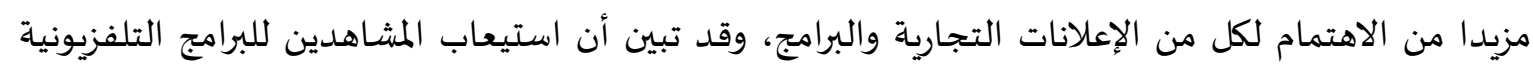


من خلال الشاشـة الكبيرة، وهي ظاهرة تتوسط تأثير حجم الشاشة على الاهتمام والتقييم والشك تجاه الإعلانات

التلفزيونياة.

التعقيب على الدراسات السابقة:

يتبين من الدراسات السابقة آنفة الذكر أنه من الممكن الاستفادة من النتائج العملية لهذه الدراسات والتي

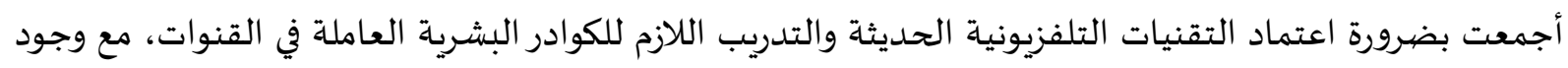
فروق تعود إلى الأسلوب الذي تتبناه البرامج الإخبارية لزيادة متابعة مشاهدي البرامج الإخبارية في التلفزيون. كما

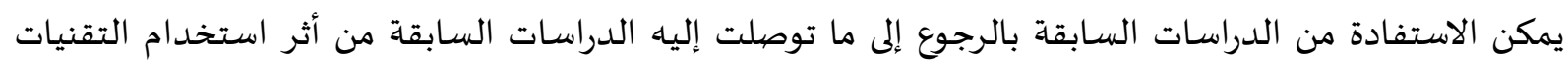

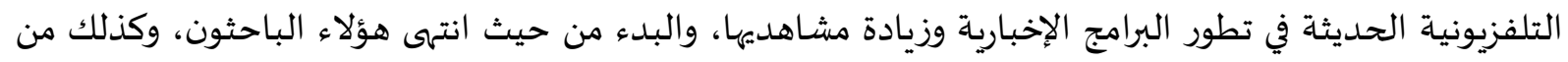

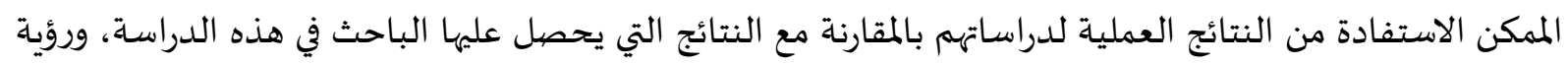

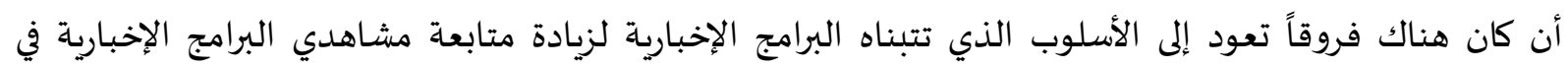
التلفزيون الأردني.

4- - 2 - منهجية الدراسة وإجراءاتها.

منهجية الدراسـة: - n

اعتمدت الدراسة على المنهج الوصفي المستي والذي يحاول تحليل وتفسير ظاهرة موضيوع البحث ويفسرها

على أمل تعميم نتائجه، ونتكلم عن تأثير التقنيات التلفزيونية الحديثة في زيادة عدد المشئاهدين.

مجتمع الدراسة وعينتها:

تكون مجتمع الدراسة من العاملين والفنيين في دائرة الأخبار في التلفزيون الأردني والمتمثلين في (رئيس تحرير،

محرر، مخرج، فني) كونهم من ذوي الاختصاص والمعرفة بدور استخدام التقنيات التلفزيونية الحديثة وأثرها على المانى

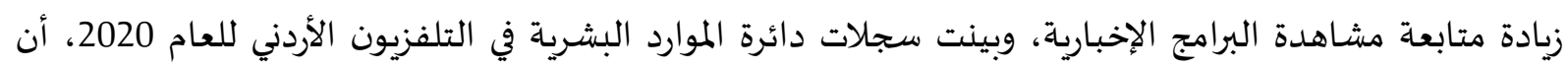

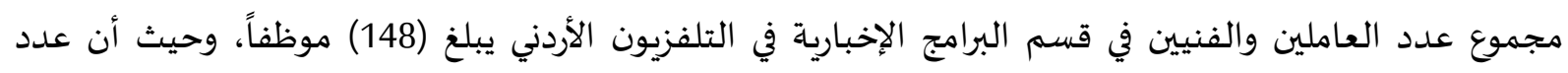

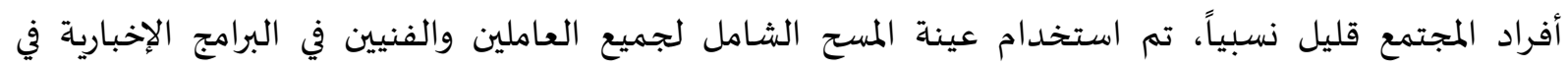
التلفزيون الأردني والمتواجدين في وقت إجراء الدراسة حيث بلغ عدد الأفراد الذين تمت مقابلتهم (110) شخص.

أداة الدراسـة: - n

بغرض الوصول إلى أهداف الدراسـة والإجابة عن أسئلتها تم استخدام الاستبانة كوسيلة لجمع المعلومات

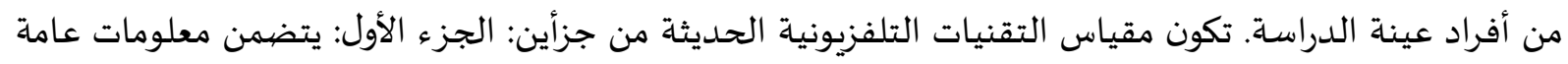

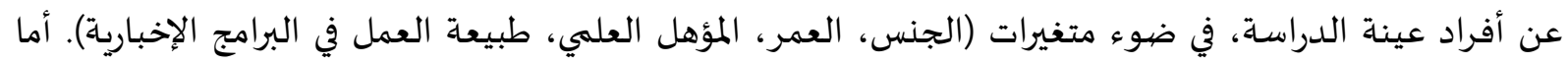

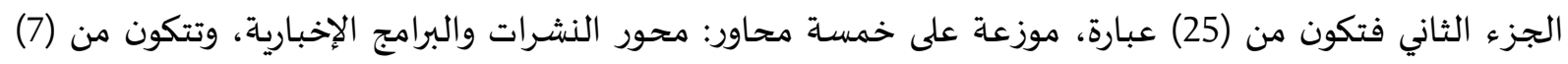

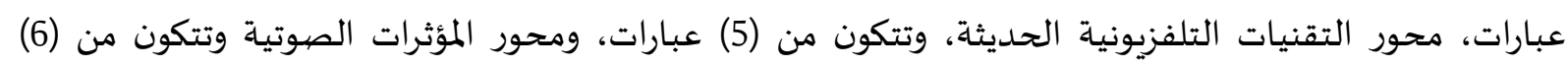
عبارات، ومحور المؤثرات السمعية، وتتكون من (3) عبارات، ومحور جودة البرامج، وتتكون من (4) عبارات. 


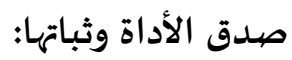

تم اخضاع المقياس إلى مؤشرات الصداق والثبات للمقياس، حيث تم عرضها على 8 محكّمين من اصححاب

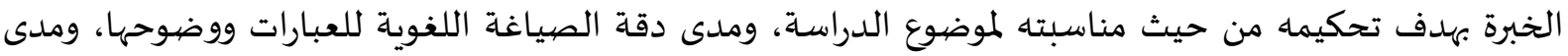

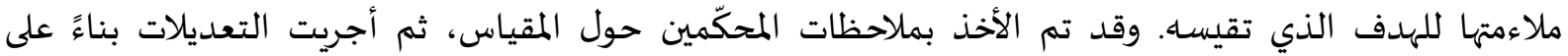
الملاحظات التي قدمها المحكّمون. ولحساب صدق البناء تم تطبيق المقياس على عينة مكونة من (30) من العاملين والفنيين في التلفزيون الأردني من خارج أفراد عينة الدراسة، حيث تم حساب قيم معاملات الارتباط بيرسون بين العبارة، والبعد الذي تنتهي لله، والدرجة الكلية للمقياس. وتم التحقق من ثبات المقياس بحساب قيم معاملات

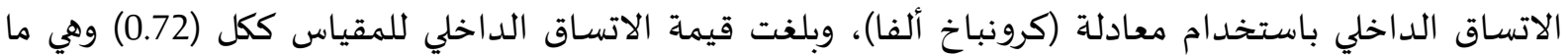

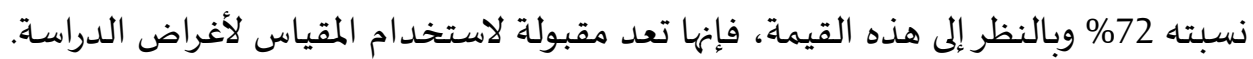

الوزن النسبي للإجابات:

وقد تم تدريج مستوى الإجابة على كل عبارة من العبارات وفق مقياس ليكرت الخماسي، وحددت بخمس مستويات، وهي: موافق بشدة (5 درجات)، موافق (4 درجات)، محايد (3 درجات)، غير موافق (2 درجتان)، غير موافق

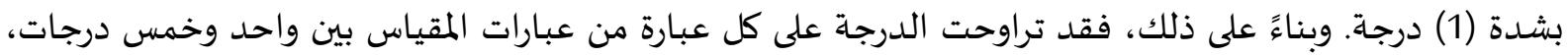

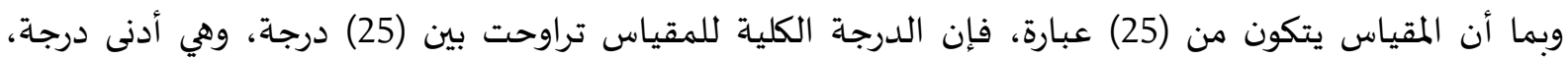
و(125) درجة، وهي أعلى درجة يمكن أن يحصل عليها المستجيب. وقد تم تصنيف المتوسطات الحسابية وفق المعيار

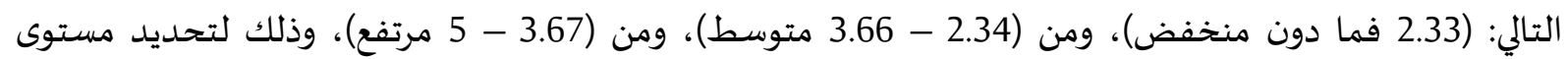
استخدام التقنيات التلفزيونية الحديثة في البرامج الإخبارية لدى أفراد عينة الدراسـة.

المعالجة الإحصيائية:

تم جمع البيانات وتحليلها عن طريق معالجتها بواسطة الحاسوب، وتم استخدام معامل كرونباخ ألفا

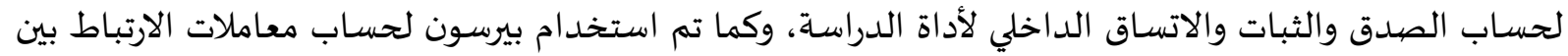
عبارات محاور الدراسة، وتم استخدام الرزمة الإحصائية (SPSS) لقياس النسب ك (الوسط، والوسيط، والانحراف المعياري)، واختبار T- Test لاختبار فرضيات الدراسة.

5- 5تائج الدراسـة ومناقشتها.

إجابة السؤال الأول: "ما التقنيات التلفزيونية الحديثة المستخدمة في البرامج والنشرات الإخبارية في التلفزيون

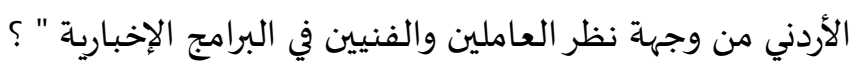

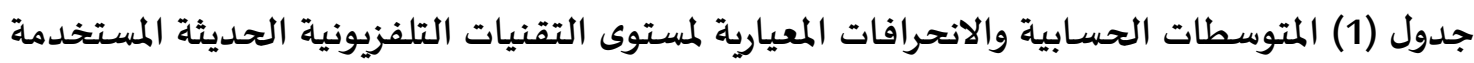
في التلفزيون الأردني

\begin{tabular}{|c|c|}
\hline المستوى العام & الانحراف المعياري \\
\hline
\end{tabular}

\begin{tabular}{|c|c|c|c|c|}
\hline 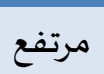 & .417 & 4.86 & النشرات والبرامج الإخبارية & 1 \\
\hline 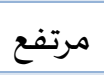 & .524 & 4.70 & التقنيات التلفزيونية الحديثة & 2 \\
\hline مرتفع & .476 & 4.77 & المؤثرات البصرية & 3 \\
\hline
\end{tabular}




\begin{tabular}{|c|c|c|c|c|}
\hline المستوى العام & الانحراف المعياري & المتوسط الحسابي* & المحاود & 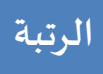 \\
\hline 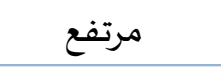 & .561 & 4.80 & المؤثرات السمعية & 4 \\
\hline مرتفع & .561 & 4.80 & جودة البرامج & 4 \\
\hline 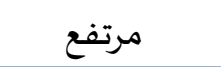 & .479 & 4.45 & التقنيات التلفزيونية الحديثة ككل & \\
\hline
\end{tabular}

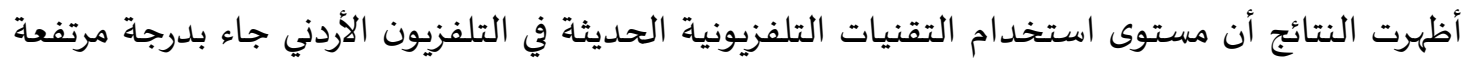

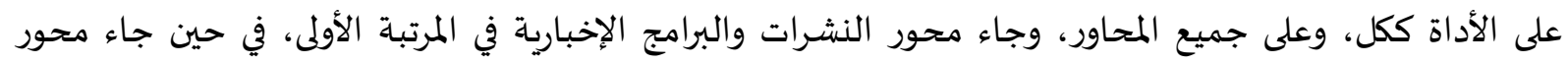
استخدام التقنيات التلفزيونية الحديثة في المرتبة الأخيرة. ويمكن تفسير هذه النتيجة في ضوء طبيعة التنافس الهائل بين القنوات الفضائية العامة في تطوير وتحديث الميثردئ

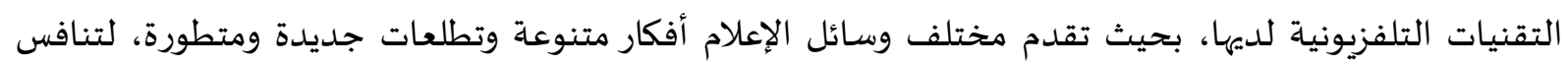

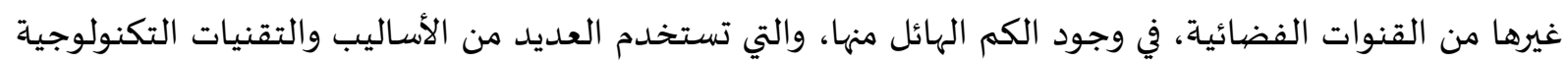

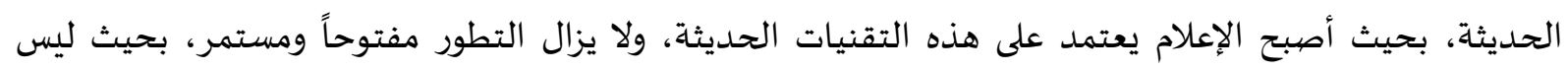

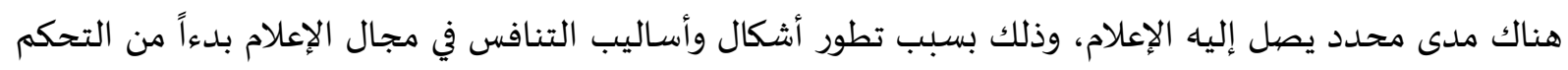

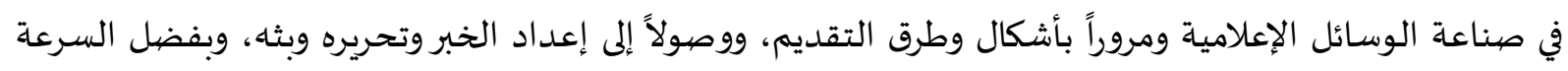

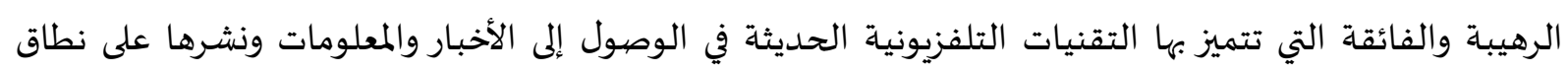
واسع، وتميزها بقدرات هائلة باستخدام تلك التقنيات ومن ناحية أخرى يمكن تفسير هذه النتيجة استناداً إلى طبيعة التلفزيون الأردني، وما يمتلكه من إمكانيات

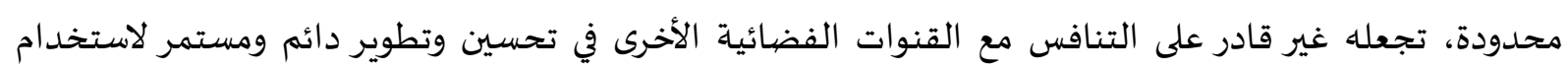

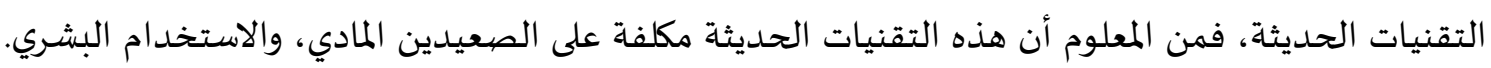

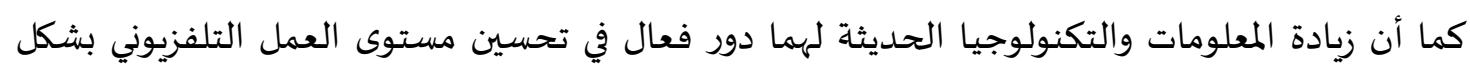

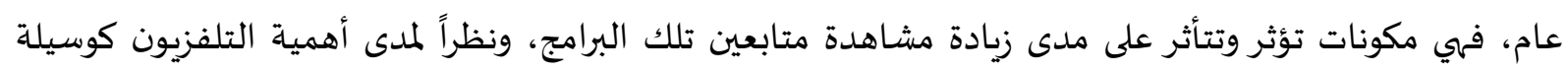

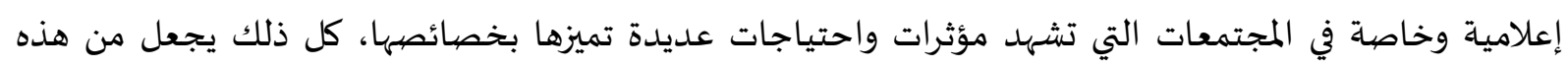

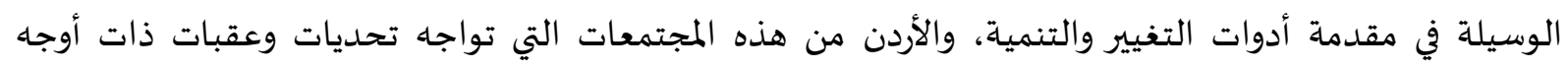

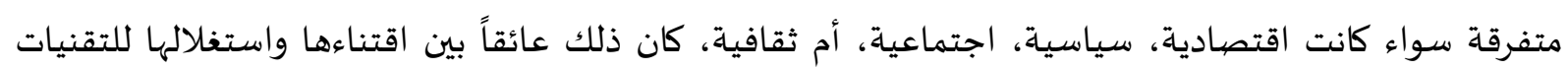

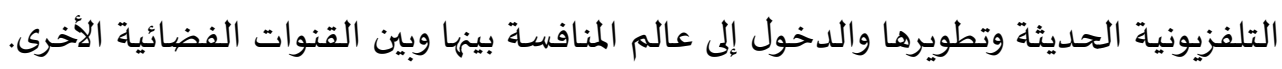

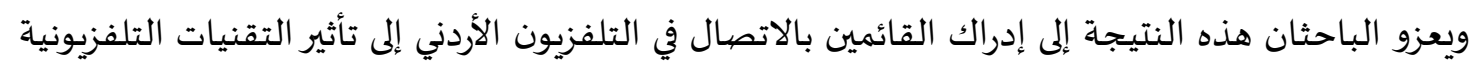

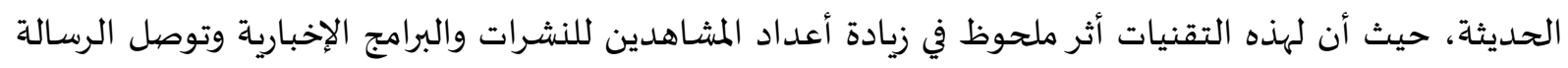

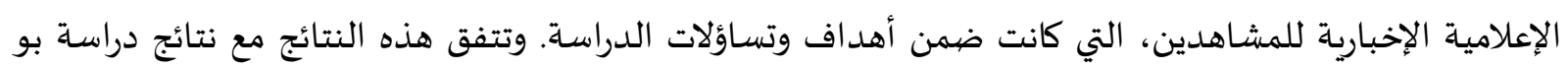

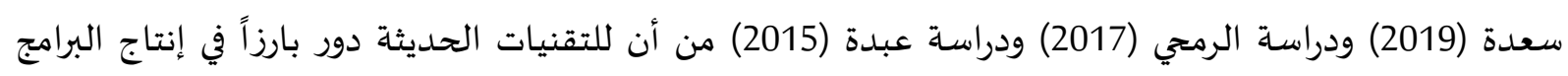
الإخبارية وفي زيادة عدد المشاهدين لهذه البرامج الإخبارية.

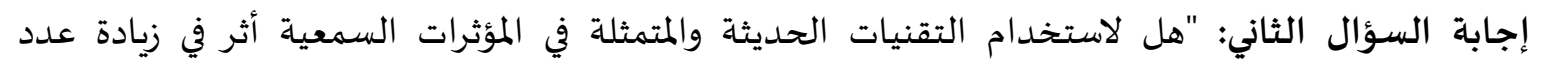

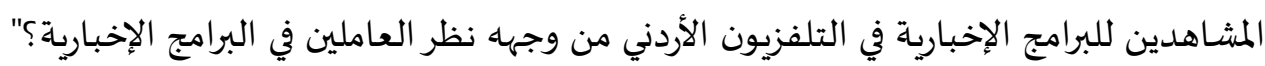


جدول (2) المتوسطات الحسابية والانحرافات المعيارية لممارسة التقنيات التلفزيونية الحديثة والمتمثلة بالمثيرات السمعية في التلفزيون الأردني من وجهة نظر العاملين والفنيين في البرامج الإخبارية مرتبة ترتيباً تنازلياً

\begin{tabular}{|c|c|c|c|c|c|}
\hline 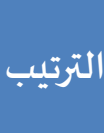 & 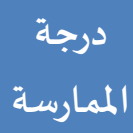 & 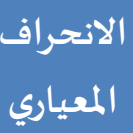 & المتوسط & 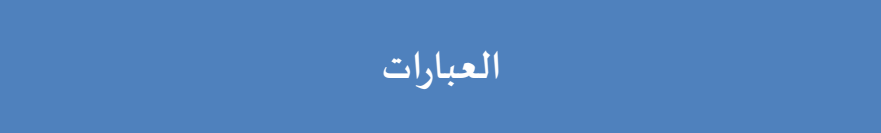 & $\hat{\imath}$ \\
\hline 1 & مرتفعة & 0.57 & 4.83 & المؤثرات السمعية لله أثر في جذب انتباه المشـاهدين & 20 \\
\hline 2 & 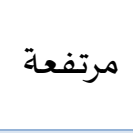 & 0.60 & 4.79 & يتضمن التلفزيون الأردني المؤثرات الصهوتية المتطورة في النشرات & 21 \\
\hline 3 & 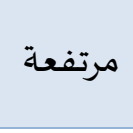 & 0.53 & 4.78 & يستخدم التلفزيون الأردني مؤثرات سمعية خاصة حديثة & 19 \\
\hline & 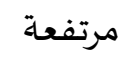 & 0.54 & 4.80 & 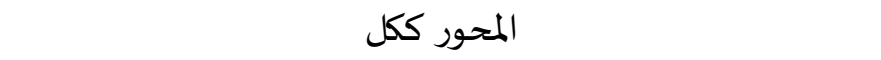 & \\
\hline
\end{tabular}

يبين الجدول (2) المتوسطات الحسابية والانحرافات المعيارية والرتبة لكل عبارة من عبارات محور المؤثرات

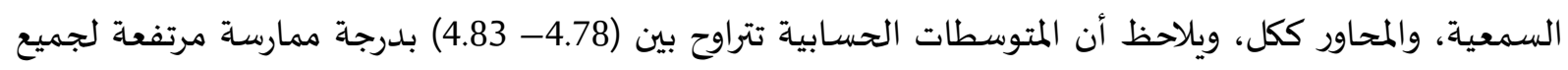
العبارات، أما المحور ككل فقد حصل على متوسط حسابي (4.80) وانحراف معياري (0.54) وبدرجة ممارسـة مرتفعة. أظهرت النتائج أن مستوى استخدام التقنيات التلفزيونية الحديثة والمتمثلة في المؤثرات السمعية الماتهاء

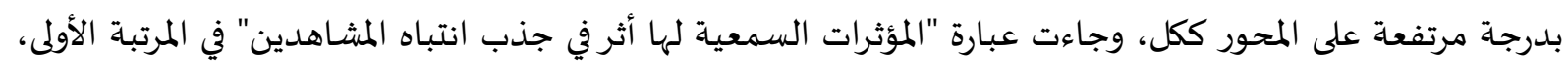

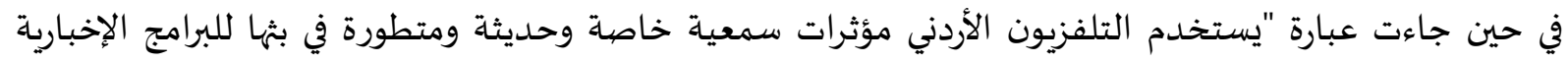
بشكل ملحوظ" في المرتبة الأخيرة.

ويمكن تفسير هذه النتيجة في ضوء قلة الإمكانيات المتوفرة لتحسين وتطوير التقنيات السمعية الحديثة،

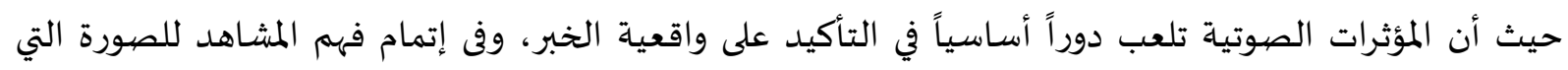
يراها على الشاشـة.

ويعتبر الصوت إحدى وسائل الاتصال الهامة بين البشر، ويعتمد عليها الإنسان في التخاطب والمحادثة

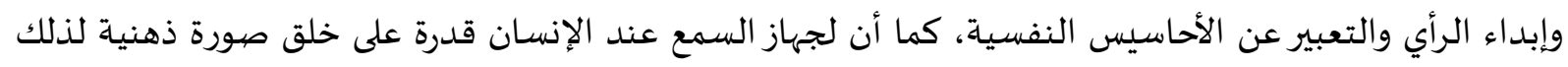

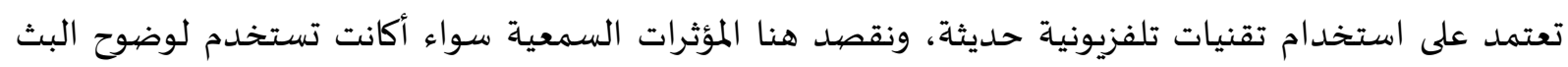

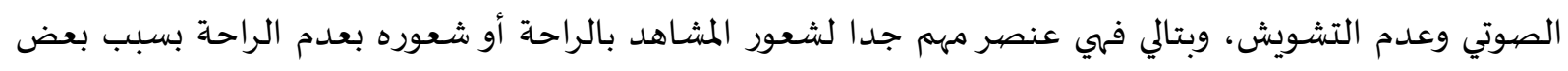

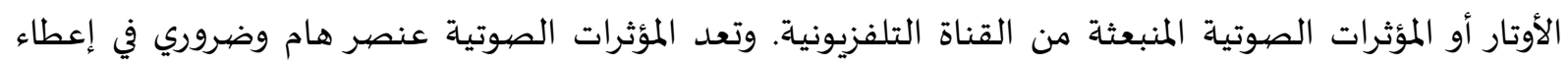

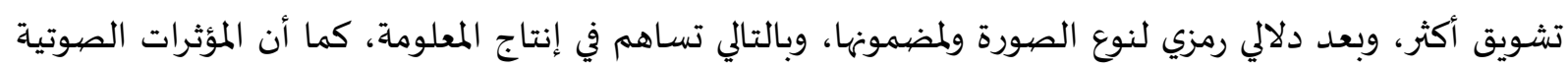

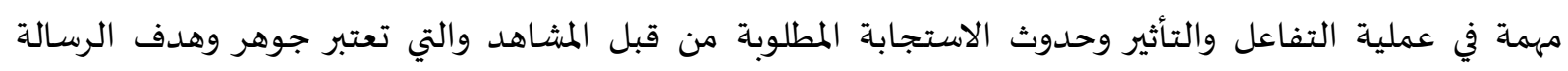

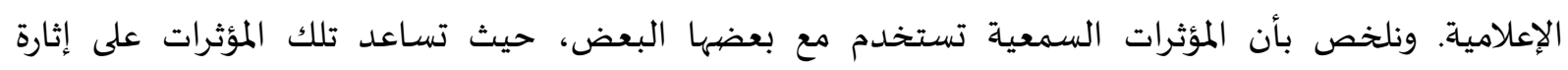

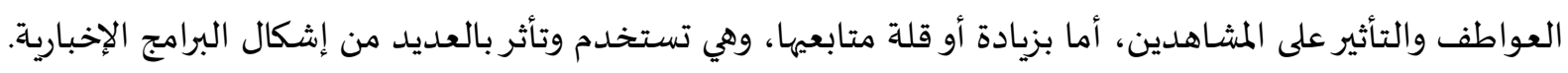

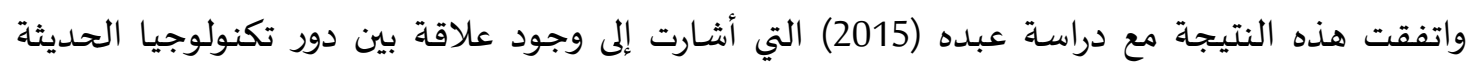

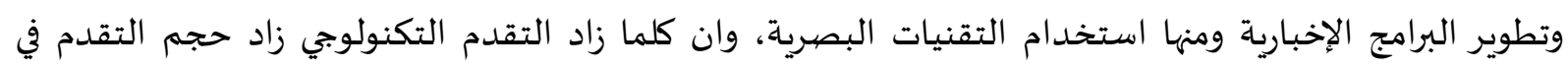
الأداء الإعلامي، واتفقت مع دراسة (Ellies, 2014) التي أشارت إلى وجود علاقة بين دور التقنيات الحديثة المتاتئة المتاحة في

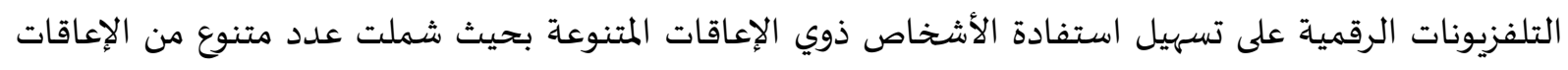

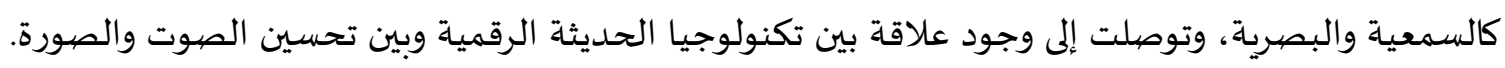


إجابة السؤال الثالث: "هل لاستخدام التقنيات الحديثة والمتمثلة في المؤثرات البصرية أثر في زيادة عدد

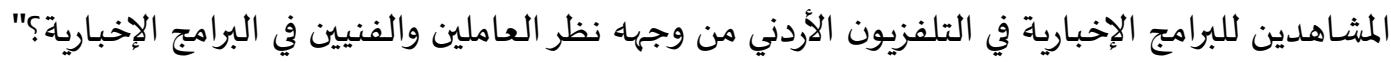

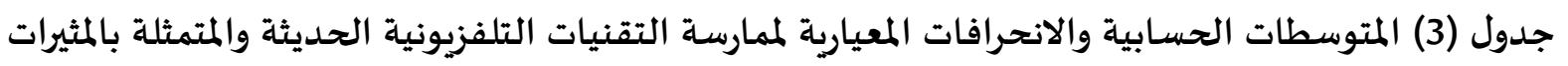

البصرية في التلفزيون الأردني من وجهة نظر العاملين والفنيين في البرامج الإخبارية مرتبة ترتيباً تنازلياً

\begin{tabular}{|c|c|c|c|c|c|}
\hline الترتيب & 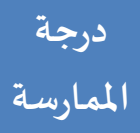 & الانتحراف & المتوسط المسابي & العبارات & $\hat{\imath}$ \\
\hline 1 & 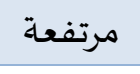 & 0.50 & 4.80 & يستخدم التلفزيون الأردني التقنيات الحديثة في وضوح الصورة & 16 \\
\hline 2 & مرتفعة & 0.54 & 4.78 & 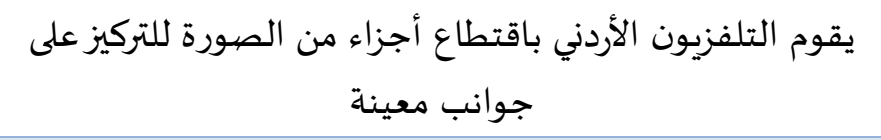 & 18 \\
\hline 3 & 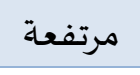 & 0.51 & 4.78 & يستخدم التلفزيون الأردني برامج المونتاج والمؤثرات الحديثة & 17 \\
\hline 4 & مرتفعة & 0.50 & 4.76 & يعرض التلفزيون الأردني رسومات بيانية رقمية حديثة في & 15 \\
\hline 5 & مرتفعة & 0.56 & 4.75 & يستخدم التلفزيون الأردني تقنيات المؤثرات البصرية والجرافيك الحديثة لعرضيك الترضية & 13 \\
\hline 6 & مرتفعة & 0.60 & 4.72 & يستعين التلفزيون الأردني بالانفوجرافيك الحديثة في النشرات & 14 \\
\hline & 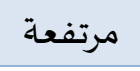 & 0.47 & 4.76 & 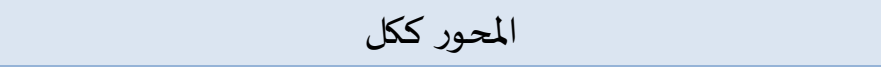 & \\
\hline
\end{tabular}

يبين الجدول (3) المتوسطات الحسابية والانحرافات المعيارية والرتبة لكل عبارة من عبارات المحور، والمحور ككل، ويلاحظ أن المتوسطات الحسابية تتراوح بين (4.72- 4.80) بدرجة ممارسة مرتفعة لجميع العبارات، أما المحور ككل فقد حصل على متوسط حسابي (4.76) وانحراف معياري (0.47) وبدرجة ممارسة مرتفعة.

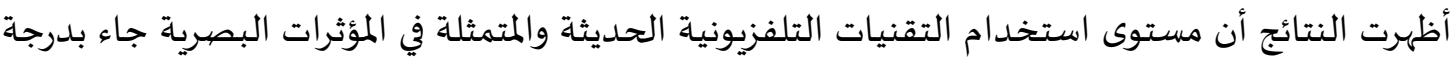
مرتفعة على المحور ككل، وجاءت عبارة "تساهم المؤثرات البصرية في التلفزيون في وضوح الصيورة" في المرتبة الأولى، في حين جاءت عبارة "يستعين التلفزيون الأردني بالانفوجرافيك في النشرات والبرامج الإخبارية" في المرتبة الأخيرة.

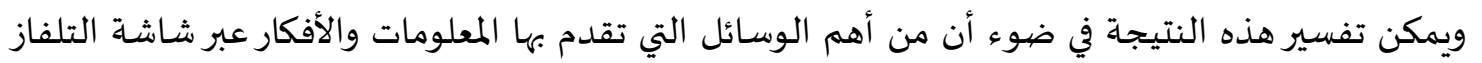

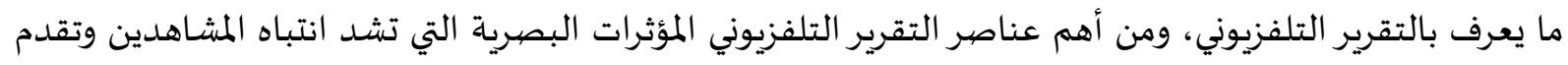

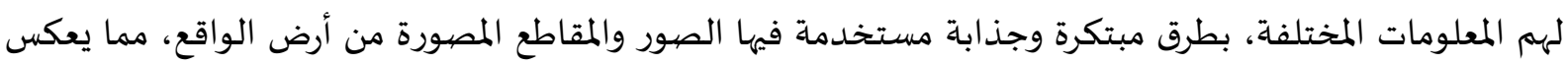
صورة واقعية عن الخبرودليلاً حقيقياً على واقعيته.

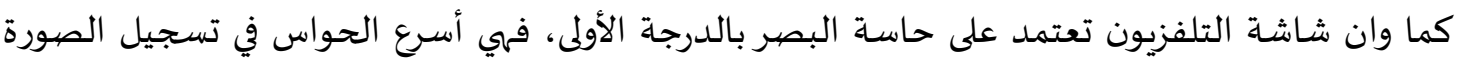

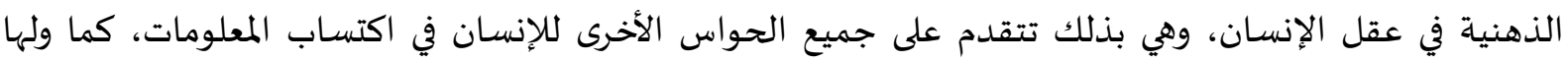

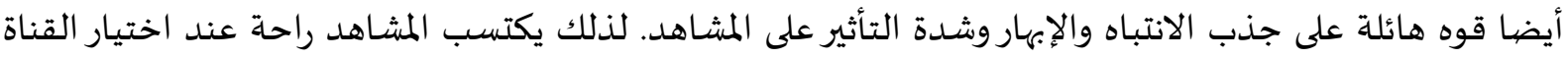

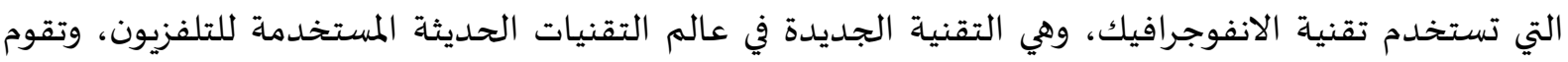

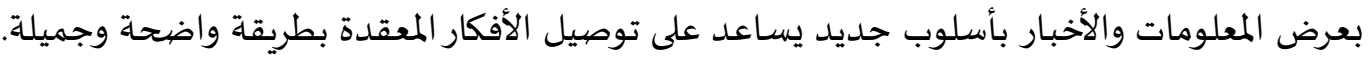

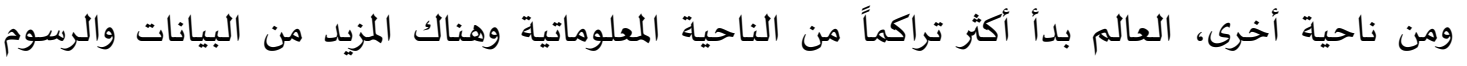
البيانية، فان التصاميم الانفوجرافيكية لها دور مهم وفعال في تبسيط هذه المعلومات والسهولة في قراءة هذه منهات 
الكميات الهائلة من البيانات المعلوماتية، والتي يسهل قراءها وتمكينها لجعل هذه البيانات أكثر سلاسة في قراءهها

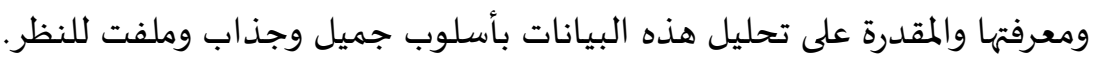

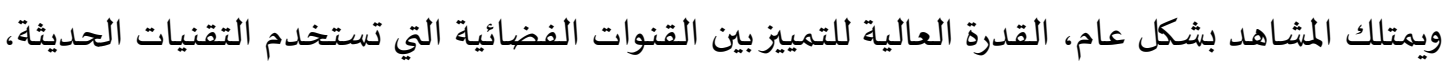

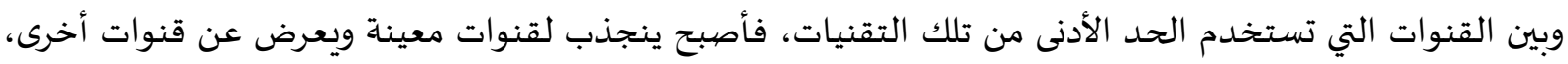

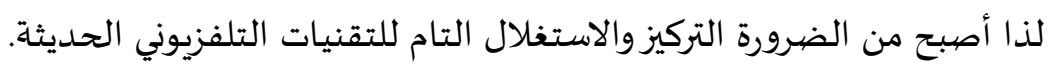

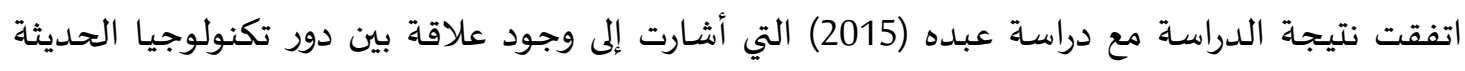

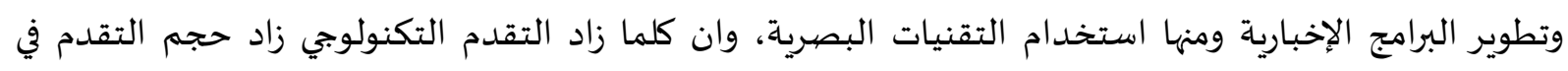

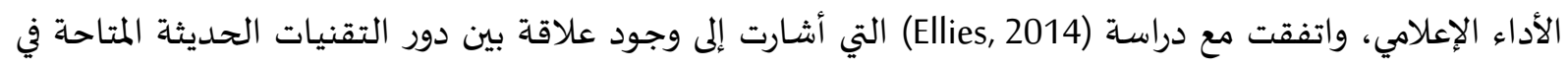

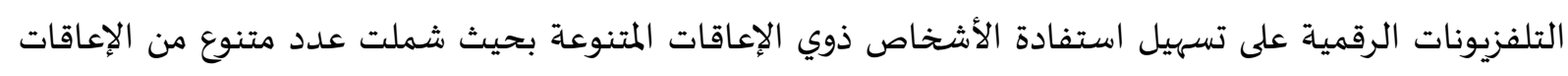

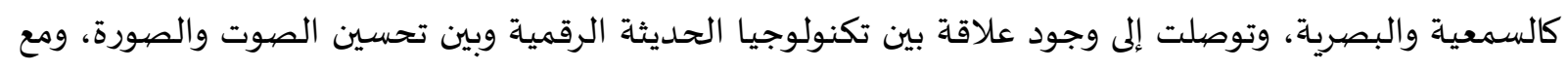

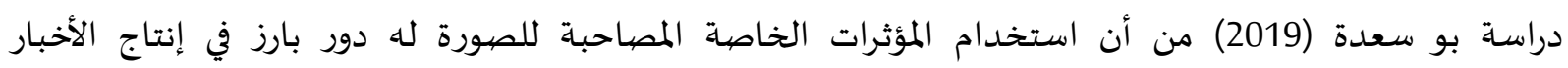
التلفزيونية وزيادة عدد المشاهدين.

إجابة السؤال الرابع: "كيف تساهم التقنيات التلفزيونية المستخدمة في البرامج الإخبارية في التلفزيون الأردني في

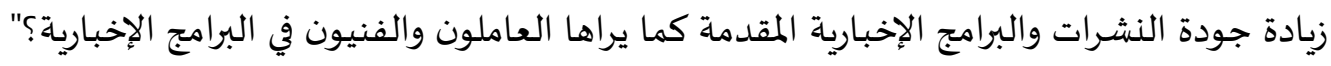

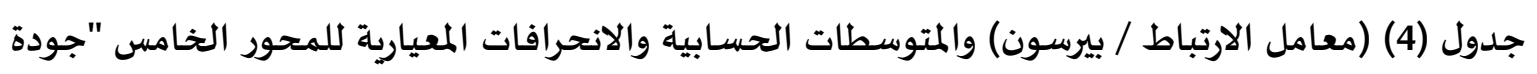

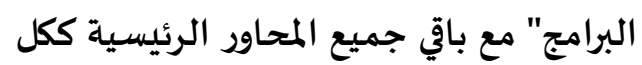

\begin{tabular}{|c|c|c|c|c|c|c|c|}
\hline ككل المحاور & السؤثمعية & البصيرية المؤثرات & التلفزيونية التقنيات & والبشرامت & جودة البرامج & \multicolumn{2}{|c|}{ المحاور الرئيسية } \\
\hline **0.884 & $* * 0.853$ & $* * 0.741$ & $* * 0.742$ & $* * 0.735$ & 1 & معامل الارتباط & \multirow{4}{*}{ جودة البرامج } \\
\hline 4.78 & 4.80 & 4.76 & 4.70 & 4.86 & 4.79 & المتوسط الحسـابي & \\
\hline 0.44 & 054 & 0.47 & 0.52 & 0.41 & 0.56 & الانحراف المعياري & \\
\hline 0.00 & 0.00 & 0.00 & 0.00 & 0.00 & 0.00 & مستوى الدلالة & \\
\hline
\end{tabular}

بينت الدراسة انه يوجد علاقة ارتباط بين المحور الخامس جودة البرامج والمحور الأول النشرات والبرامج

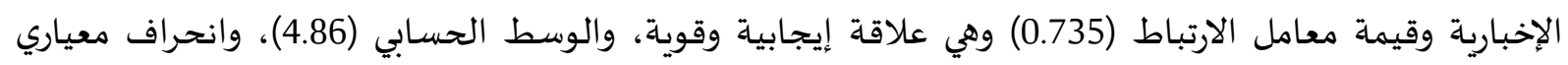
(0.41) وعند مستوى دلالة (0.00) وهي دالة إحصائيا.

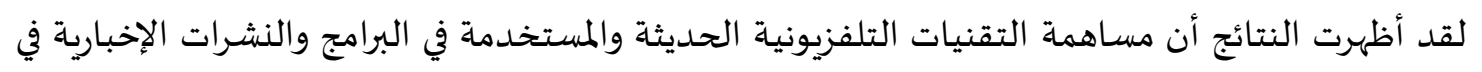

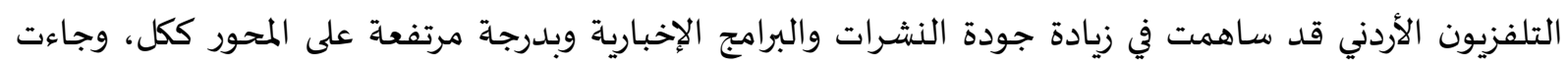

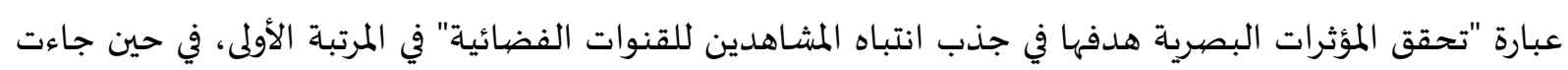
عبارة "يسهم الوسائط المتعددة في التلفزيون الأردني على زيادة جودة النشرات والبراتئرجئ الإخبارية " في المرتبة الأخيرة.

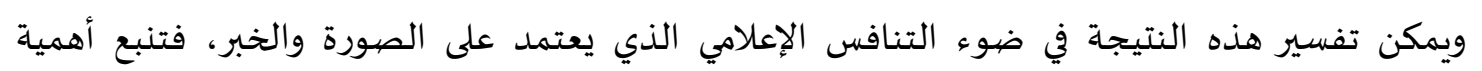

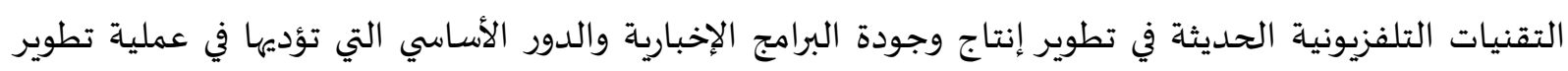

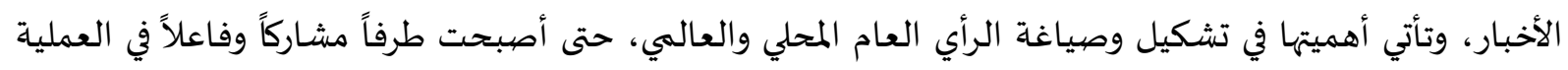


الاتصالية، بحيث تمثل جودة الإنتاج محوراً رئيسياً تدور حوله كافة الأنشطة الإخبارية، وبتالي فهي تعتبر أمرا ضرورياً ومهماً في دعم التقنيات التلفزيونية الحديثة.

ومن المعلوم أيضا أن التقنيات التلفزيونية الحديثة قد أدت إلى تغيرات ملموسة ليس من من جانب الشكل

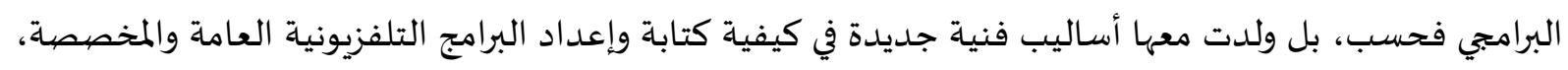

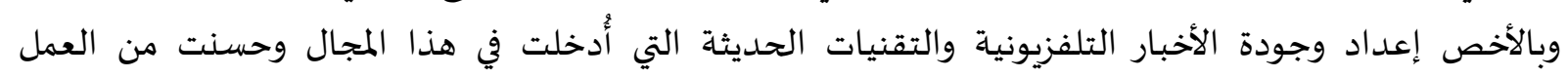
الإخباري شكلاً ومضموماً.

كما أن تشخيص جودة تقنيات التلفزيون الأردني في الوقت الراهن يحتاج إلى فحص البيئة الداخلية من

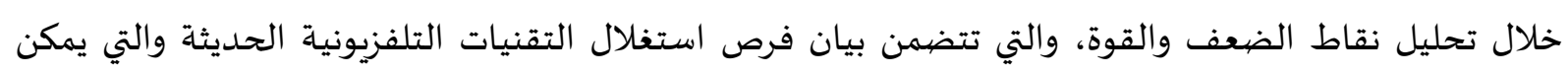

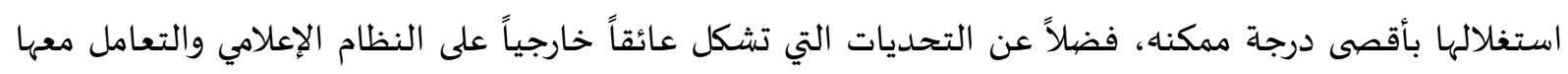

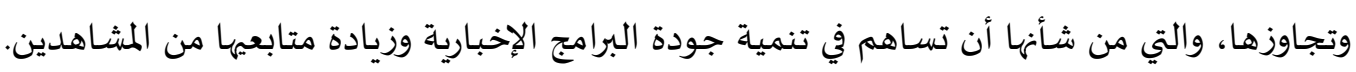

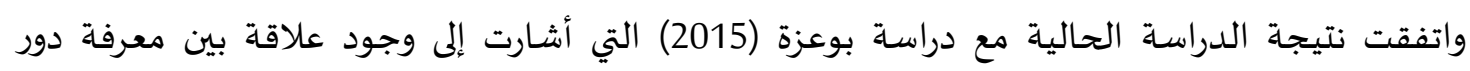

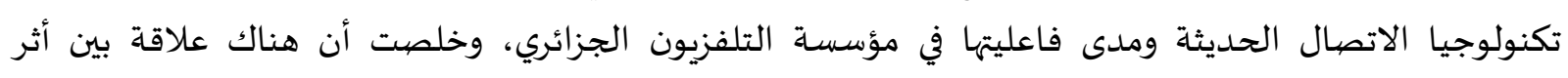

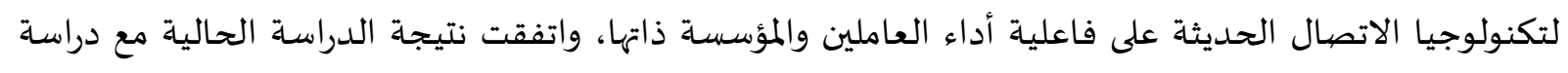

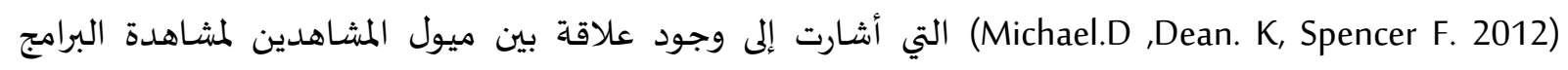

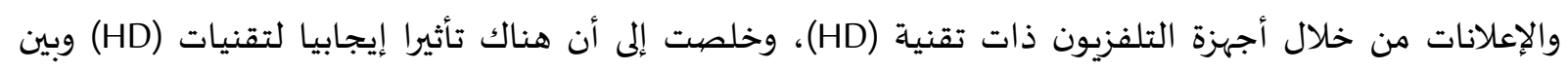

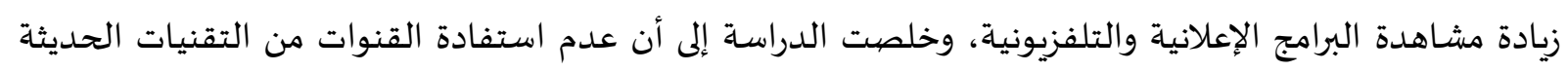

قد يعرضها إلى عدد من المشكلات أهمها قله عدد مشاهدة المانديها.

\section{فحص فرضيات الدراسة}

Regression liner ) تم الإجابة على فرضيات الدراسة باستخدام حساب معادلة الانحدار الخطي البسيط لفرابة module)

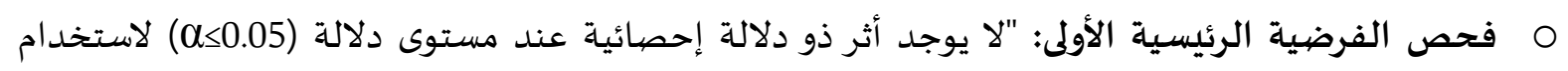

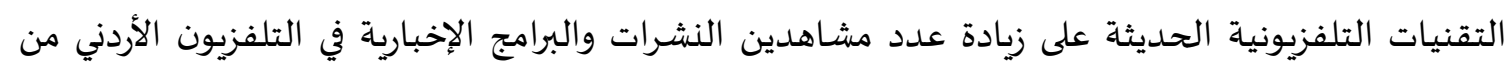

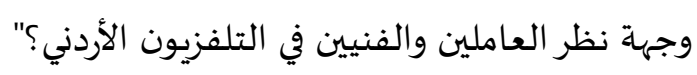

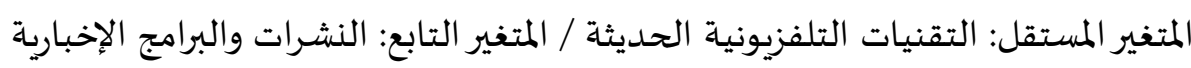

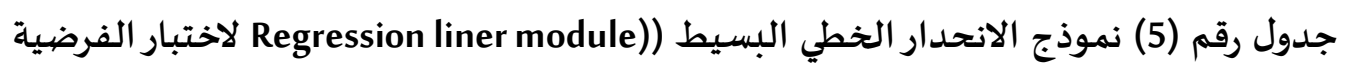

\begin{tabular}{|c|c|c|c|c|c|c|}
\hline القرار & مستوى الدلالة & قيمة (ف) & مربع الوسط & درجة الحرية & مجموع المربعات & النموذج \\
\hline \multirow{3}{*}{ إحصائيا } & \multirow{3}{*}{$*_{0} 0.00$} & \multirow{3}{*}{172.11} & 11.82 & 1 & 11.62 & الانحدار الخطي \\
\hline & & & 0.068 & 108 & 7.29 & نسبة الخطاء \\
\hline & & & & 109 & 18.91 & المجموع \\
\hline
\end{tabular}

* 0.05 ( دال عند مستوى دلالة إحصيائية

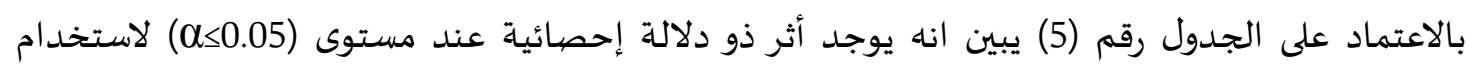

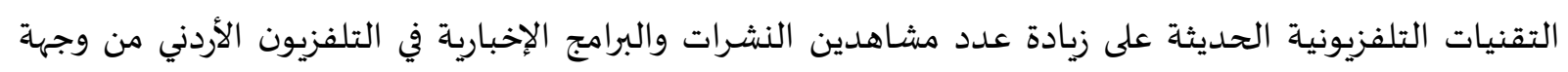

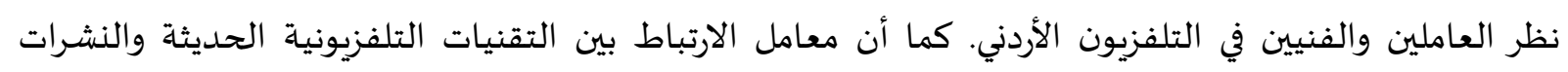
والبرامج الإخبارية تساوي (0.784) وهي علاقة قوية وإيجابية. 
O فحص الفرضية الفرعية الأولى: "لا يوجد أثر ذو دلالة إحصائية عند مستوى دلالة (a 0.05$)$ لاستخدام

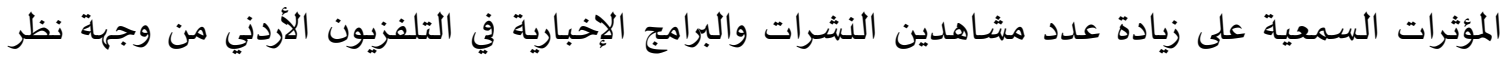

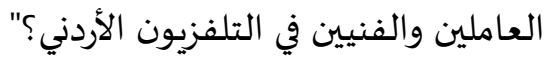

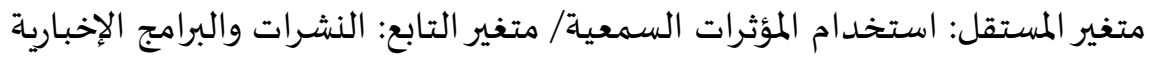

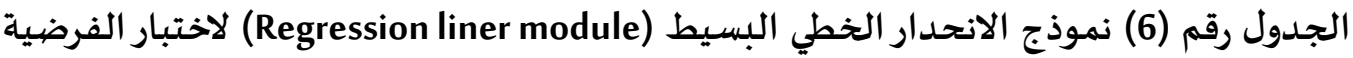

\begin{tabular}{|c|c|c|c|c|c|c|}
\hline القرار & الدلالة & قيمة (ف) & مربع الوسط & درجة الحرية & مجموع المربعات & النموذج \\
\hline \multirow{3}{*}{ إحصائيا } & \multirow{3}{*}{$* 0.00$} & \multirow{3}{*}{186.32} & 11.97 & 1 & 11.98 & الانحدار الخطي \\
\hline & & & 0.064 & 108 & 6.94 & نسبة الخطاء \\
\hline & & & & 109 & 18.91 & المجموع \\
\hline
\end{tabular}

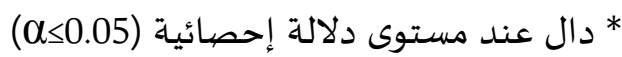

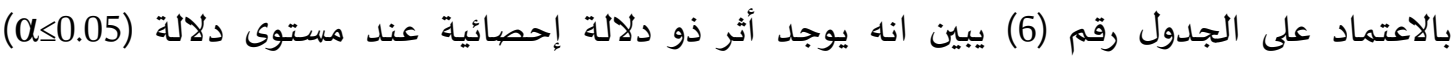

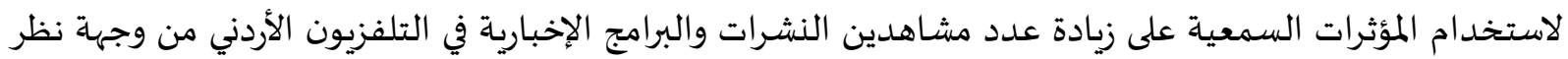

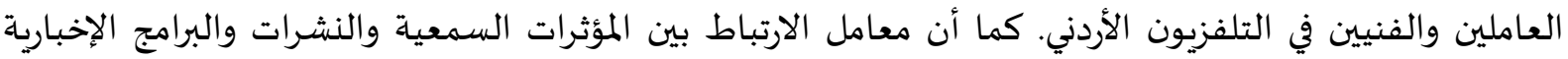
تساوي (0.796) وهي علاقة قوية وإيجابية.

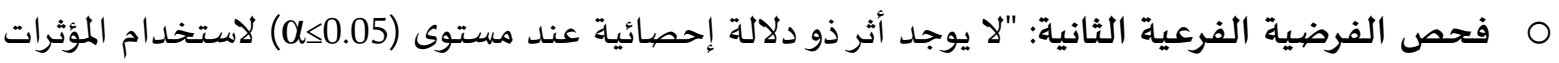

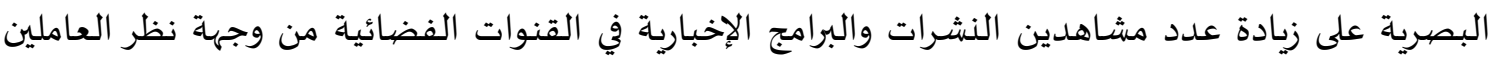

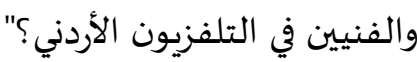

متغير المستقل: المؤثرات البصرية/ متغير التئي التابع: النشرات والبرامج الإخبارية

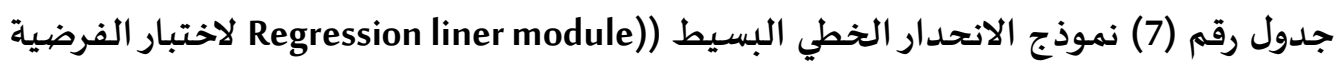

\begin{tabular}{|c|c|c|c|c|c|c|}
\hline القرار & مستوى الدلالة & قيمة (ف) & مربح الوسط & درجة الحرية & المربعات متموع & النموذج \\
\hline \multirow{3}{*}{ دال إحصائيا } & \multirow{3}{*}{$*_{0} 0.00$} & \multirow{3}{*}{220.31} & 12.69 & 1 & 12.69 & الانحدار الخطي \\
\hline & & & 0.058 & 108 & 6.22 & نسبة الخطاء \\
\hline & & & & 109 & 18.91 & المجموع \\
\hline
\end{tabular}

* دال عند مستوى دلالة إحصائية (1<0.05)

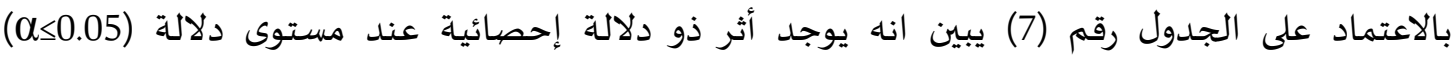

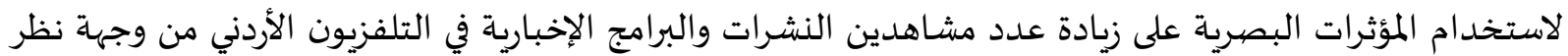

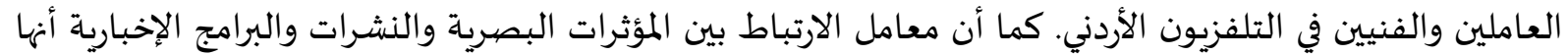
تساوي (0.819) وهي علاقة قوية وإيجابية.

\section{التوصيات والمقترحات.}

1- - ضرورة الاهتمام بوضع الخطط والسياسات لمواجهة استخدام التقنيات التلفزيونية الحديثة والسعي لرقمنة

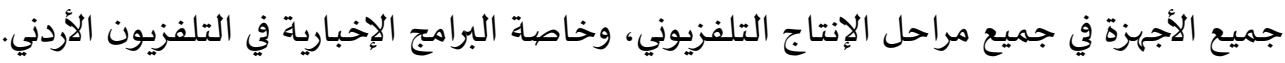

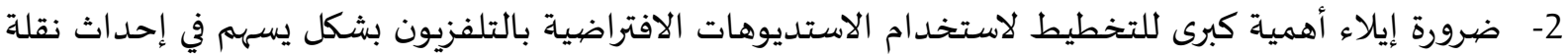
نوعية في الإنتاج التلفزيوني بما تمتاز باه من جودة وجماليات، وخلق تواصل مع المشاهدين بصورة جذابة المابة. 
3- ضرورة الاستفادة بشكل متكامل من التقنيات التلفزيونية الحديثة في الإضاءة والتصميم والصوت والصورة

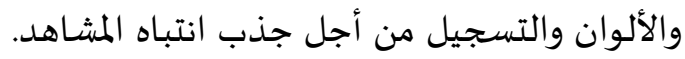
4- - ضرورة ابتعاث الفنيين في مجال التصوير والصوت والإضاءة والجرافيك والمونتاج للخارج لاكتساب الخبرة والمهارات وتبادل الخبرات في المجالات المرتبطة بالإنتاج التلفزيوني.

- - إبراهيم، علي (2017). التكامل بين الإعلام التقليدي والجديد. عمان، دار المعتز للنشروالتوزيع.

- - م ابو رستم، رستم (2016). الأجهزة والمعدات في التلفزيون، عمان، دار المعتز للنشر والتوزيع.

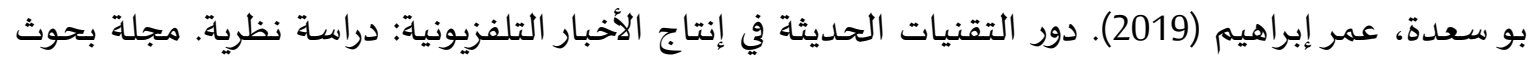

العلاقات العامة الشرق الأوسط، الجمعية المصرية للعلاقات العامة، القاهرة، 23(1).

بوعزة، جمال الدين بن عائشة (2015). استخدام تكنولوجيا الاتصال الحديثة في التلفزيون الجزائري: دراسة

وصفية تحليلية بمحطة ورقلة الجهوية. رسالة ماجستير غير منشورة، جامعة قاصدي مرباح، ورقلة، الجزائر. ثمار، يوسف (2007). تحليل المحتوى للباحثين والطلبة الجامعيين، الجزائر، طاكسيج للدراسات والنشر والتوزيع.

- الجمال، نجلاء (2013). فن المونتاج التلفزيوني. القاهرة، الدار المصرية اللبنانية.

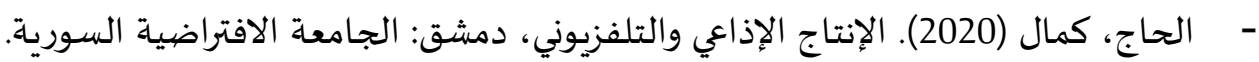

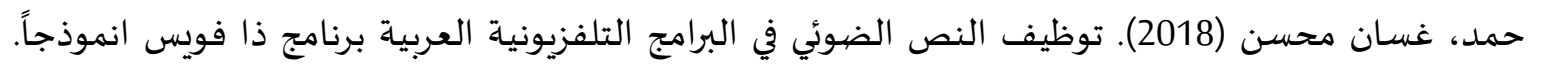

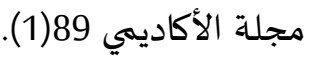
الرمجي، تمارا محمد (2018). توظيف الإعلام الرقهي في إنتاج البرامج الإخبارية في التلفزيون الأردني. رسالة ماجستير غير منشورة جامعة الشرق الأوسط، عمان، الأردن. تونمان. - الزعبي، أشرف فالح (2017). تأثير الصورة على المشاهدة في التلفزيون الأردني من خلال التقنيات والتكنولوجيا

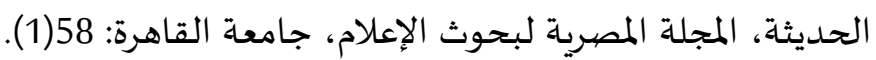
سليم، عبد النبي (2014). الإعلام التلفزيوني، ط2 القاهرة، الدار المصرية اللبنانية.

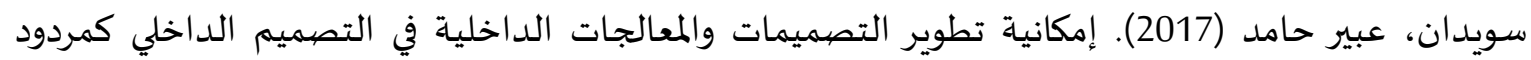

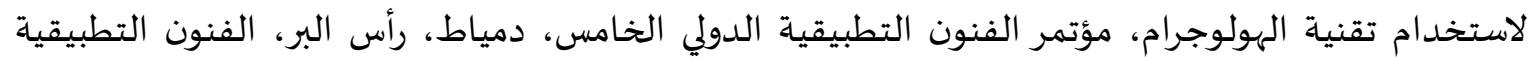
والتوقعات المستقبلية في تاريخ 21- 23 مارس. الشيخ، محمد بكري أحمد (2014). تحديات استخدامات التقنية الرقمية في الإنتاج التلفزيوني: تلفزيون

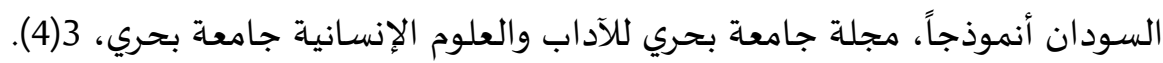
- ـ الصادق رابح (2004)، الإعلام والتكنولوجيات الحديثة، العين، الامارات العربية المتحدة. صادق، عباس مصطفى (2008). الإعلام الجديد، عمان: دار الشروق للنشروالتوزيع.

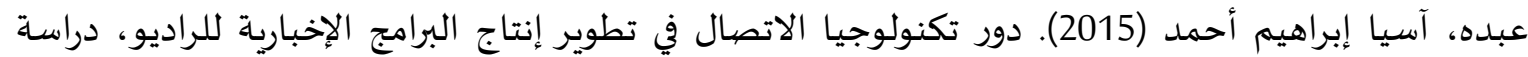
تطبيقية على الإذاعة السودانية في الفترة 2011 - 2014. أطروحة دكتوراه غير منشورة، جامعادة السودان السيان للعلوم والتكنولوجيا. 
محب الدين، يارا أحمد، ومحمد، سالم عبد البديع، وجاد، عزمي نبيل (2011). معايير توظيف تقنيات

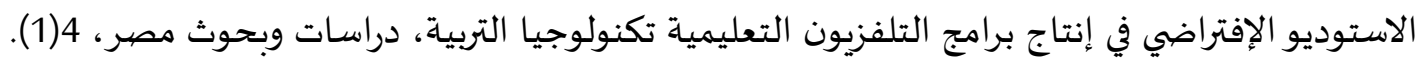

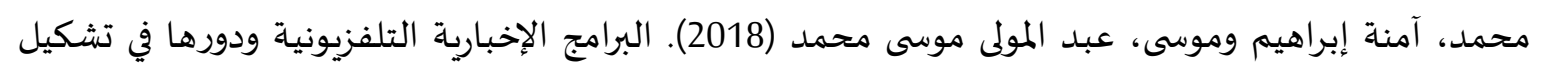

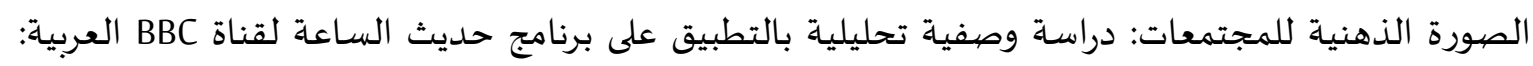

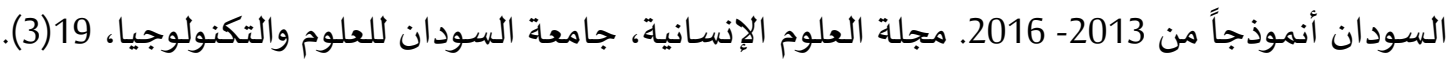
المصري، عز الدين عطية (2010). الدراما التلفزيونية مقوماتها وضوابطها الفنية. رسالة ماجستير غير منشورة، الإنها الجامعة الإسلامية غزة، فلسطين.

معوض، محمد ابراهيم وبركات، عبد العزيز (2015). البرامج الإذاعية والتلفزيونية. القاهرة، دار الكتاب الحديث.

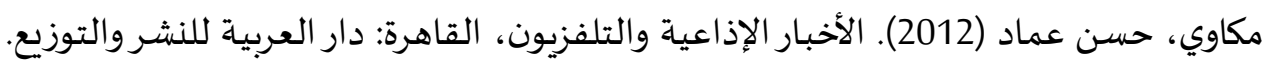

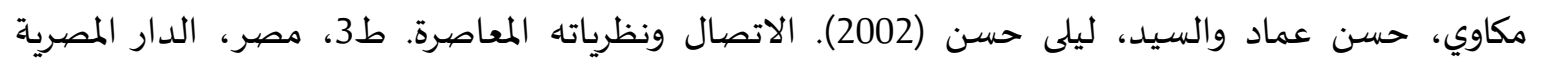
اللبنانية للنشر. - وليد، عمشة (2006). مذكرة حول اقتصاديات الإنتاج الإعلامي، دمشق: منشورات جامعة دمشق. ثانياً- المراجع بالإنجليزية:

- Ballast, D.I interior design reference manual professional pub Inc. Belmont, CA, 2004, P44.

- Baran, Stanly J., (2009), "Introduction to Mass Communication, Media Literacy and Culture" Fifth Edition, (Boston: Mc Graw Hill).

- Baran, Stanly J., (2009), "Introduction to Mass Communication, Media Literacy and Culture" Fifth Edition, (Boston: Mc Graw Hill).

- Ellis, K. (2014). Digital television flexibility: A survey of Australians with disability. Media International Australia (150): pp. 96- 105. Source Title. Media International 2014.

- Hudspeth, M. What Does Color Mean Machine design, 6(1), Circle157.

- Michael D. McNiven, Dean Krugman, Spencer F. Tinkham (2012), The Big Picture for Large- Screen Television Viewing for Both Programming and Advertising, Audiences Are More Attentive, More Absorbed, and Less Critical. Journal of Advertising Research, DOI: 10.2501/JAR- 52 